\title{
The negative impact of biomass burning and the Orinoco low-level jet on the air quality of the Orinoco River basin (edited by Dr. M. Grutter)
}

\author{
Camila RODRIGUEZ-GOMEZ ${ }^{1+}$, Ghisliane ECHEVERRY ${ }^{2+}$, Alejandro JARAMILLO ${ }^{1}$ and Luis A. LADINO ${ }^{1 *}$ \\ ${ }^{1}$ Instituto de Ciencias de la Atmósfera y Cambio Climático, Universidad Nacional Autónoma de México, Mexico City, \\ Mexico \\ ${ }^{2}$ Facultad de Ciencias Naturales y Exactas, Universidad del Valle, Cali, Colombia \\ ${ }^{+}$These authors contributed equally to this work \\ *Corresponding author: luis.ladino@atmosfera.unam.mx
}

Received: September 15, 2020; accepted: February 3, 2021

\begin{abstract}
RESUMEN
La quema de biomasa (BB, por sus siglas en inglés) es una actividad común en los países en desarrollo e identificada como una grave amenaza de contaminación del aire. El presente trabajo evalúa por primera vez la calidad del aire de la ciudad más grande de las extensas llanuras colombianas $\left(250.000 \mathrm{~km}^{2}\right)$, a partir de mediciones durante tres años consecutivos (2017-2020). Aunque durante la mayor parte del año la calidad del aire en Villavicencio es buena en términos de $\mathrm{PM}_{10} \mathrm{y} \mathrm{O}_{3}$, durante la estación seca (de febrero a abril) los niveles de contaminación de ambos contaminantes superan los límites recomendados por la Organización Mundial de la Salud. La combinación del chorro de bajo nivel del Orinoco (OLLJ, por sus siglas en inglés) con las emisiones de BB de los llanos venezolanos y colombianos se identificó como la principal causa de los episodios de mala calidad del aire observados durante la estación seca en ésta ciudad. Se identificó el carbono orgánico derivado de un reanálisis como el componente principal de las altas concentraciones de $\mathrm{PM}_{10}$ durante la estación seca. Sin embargo, también se encontró que el polvo mineral y las partículas de sal marina juegan un papel importante en la mala calidad del aire observada en Villavicencio y probablemente a lo largo de la Cuenca del Río Orinoco. Finalmente se encontró que, entre noviembre y marzo, el OLLJ es un mecanismo eficiente para el transporte de contaminantes atmosféricos desde el Océano Atlántico y las llanuras de la Cuenca del Río Orinoco en Venezuela y Colombia hacia las regiones del sur de Colombia, y en ocasiones llegando a Ecuador.
\end{abstract}

\begin{abstract}
Biomass burning (BB) is a common activity in developing countries and has been identified as a serious air pollution threat. The present work for the first time evaluates the air quality of the largest town in the extensive Colombian savannas $\left(250,000 \mathrm{~km}^{2}\right)$, from measurements over three consecutive years (2017-2020). Although the air quality in Villavicencio is good in terms of $\mathrm{PM}_{10}$ and $\mathrm{O}_{3}$ for most of the year, pollution levels for both pollutants exceed the World Health Organization recommended limits during the dry season (February to April). The combination of the Orinoco low-level jet (OLLJ) and BB emissions from the Venezuelan and the Colombian savannas was identified as the main cause of poor air quality episodes during the dry season in this city. Organic carbon derived from reanalysis was identified as the main component of the high $\mathrm{PM}_{10}$ concentrations during the dry season. However, mineral dust and sea salt particles were also found to play an important role in the poor air quality observed in Villavicencio and likely along the Orinoco river basin region. Finally, between November and March, the OLLJ was found to be an efficient mechanism for the transport of air pollutants from the Atlantic Ocean and the savanna regions in the Orinoco River Basin in Venezuela and Colombia towards southern regions of Colombia, and in some cases even reaching Ecuador.
\end{abstract}

Keywords: Regional air pollution, Northern South America, Long-range transport, Orinoco River Basin, Villavicencio, Organic carbon. 


\section{Introduction}

Urban centers concentrate population, resources, and a large variety of anthropogenic activities that result in poor air quality conditions. The World Health Organization (WHO) estimates that every year, more than six million premature deaths worldwide can be attributed to indoor and outdoor air pollution (WHO, 2018). In South America, the air quality problem is a growing concern as $80 \%$ of the population (i.e., 260 million people) lives in urban centers, demanding more energy, transport, and industrial development (Arsht, 2013). The main sources of air pollutants in urban zones are the anthropogenic emissions from the incomplete combustion of fossil fuels, road dust, and industrial activities (Teichmann, 2010). Additionally, biomass burning (BB) emissions originate from regional or local agricultural activities and wildfires. These emissions contribute to the increase of atmospheric gases such as volatile and semi-volatile organic compounds (VOCs), $\mathrm{CO}, \mathrm{NOx}, \mathrm{CH}_{2} \mathrm{O}, \mathrm{CH}_{4}$, and $\mathrm{SO}_{2}$. Additionally, particulate matter (PM) also increases with important contributions of light-absorbing aerosol particles such as black carbon (BC), particle-bound polycyclic aromatic hydrocarbons (pPAHs), and organic carbon (OC), among others (Schultz et al., 2008; Andreae and Merlet, 2001; McDonald et al., 2018; Dignon, 1992; Aurell and Gullett, 2013; Jaffe and Wigder, 2012; Phuleria et al., 2005; Garcia-Hurtado et al., 2014; Kollanus et al., 2016). It has been reported that OC is an important by-product of BB, representing two-thirds of its mass (Duan et al., 2004; Cachier et al., 1995).

The impacts of BB on air quality has been evaluated in several South American countries such as Colombia (Mendez-Espinosa et al., 2019; Hernandez et al., 2019; Rincón-Riveros et al., 2020), Chile (Cuchiara et al., 2017; Rubio et al., 2015; Marín et al., 2017), Brazil (Oliveira et al., 2011; Urban et al., 2012; dos Santos et al., 2014), and Venezuela (Hamburger et al., 2013). These studies remark the degradation of air quality in urban centers due to the increased concentration of $\mathrm{PM}_{10}, \mathrm{PM}_{2.5}, \mathrm{CO}$, and ozone during the $\mathrm{BB}$ season. It is also important to note that African dust is another important source of aerosol particles in northern South America (NSA), most frequently observed between February and August (Prospero et al., 2014; Kishcha et al., 2014; Ben-Ami et al., 2010). Dust outbreaks can increase $\mathrm{PM}_{10}$ by $27.5 \mu \mathrm{g} \mathrm{m}^{-3}$ in Cayenne (French Guiana) (Prospero et al., 2014),
$50 \mu \mathrm{g} \mathrm{m}^{-3}$ in Medellín and Bogotá, Colombia (Méndez et al., 2018), and $26 \mu \mathrm{g} \mathrm{m}^{-3}$ in Balbina, Brazil (Formenti et al., 2001).

Long-range and regional transport of BB emissions constitutes one of the largest sources of transboundary pollution (Bergin et al., 2005; Adame et al., 2012; Castro Videla et al., 2013; Hamburger et al., 2013; Cottle et al., 2014; Donnelly et al.,2015; Kollanus et al., 2016). South America is the second-largest contributor of BB emissions in the world, after Africa, with $16 \%$ of the global emissions (Koch et al., 2007; Van Der Werf et al., 2010). In addition to air pollution degradation, BB has local, regional, and global climate effects such as changes in the land use, surface albedo, and the radiative budget, as well as the intensification of drought periods, and the modification of precipitation patterns, among others (Van Der Werf et al., 2010; Thornhill et al., 2018).

Most of the BB in the NSA region occurs in the Brazilian Amazon and the Venezuelan and the Colombian savannas (i.e., the Orinoco River basin, ORIB) (Dwyer et al., 2000; Armenteras-Pascual et al., 2011). The burned areas are a direct consequence of economic practices, such as change of land use for agriculture and human occupation (Pivello, 2011; Cordeiro et al., 2014). Every year, 1,355 tons of $\mathrm{PM}_{10}$ are emitted every month by BB in the ORIB, mostly during the dry season (Hernandez et al., 2019). These fires typically take place between December and May (Hamburger et al., 2013), with the highest fire activity observed between January and February for Colombia, and from January to May in Venezuela (Hernandez et al., 2019). Besides the BB activity during the dry season, the northeast trade winds intensify creating the so-called Orinoco low-level jet (OLLJ) (Torrealba and Amador, 2010; Jiménez-Sánchez et al., 2019), that can potentially transport emissions from Venezuela to Colombia as previously shown by Hernandez et al. (2019). This phenomenon occurs during boreal winter, i.e., December-April, as the InterTropical Convergence Zone (ITCZ) moves to its southernmost position while the North Atlantic subtropical high is closest to the Equator (Poveda et al., 2006; Jiménez-Sánchez et al., 2019). The ITCZ position determines the length of both the dry and the BB seasons (Pulwarty et al., 1998).

Recently, using off-line methods to determine the $\mathrm{PM}_{10}$ concentrations with a temporal resolution of 
$24 \mathrm{~h}$, Hernandez et al. (2019) found that during the Venezuelan BB season, particles from the burned areas affect the air quality of two middle size cities in the Colombian ORIB (i.e., Yopal and Arauca) between April and May, 2015. The authors mentioned a possible connection between the transport of air pollutants and the OLLJ; however, they were unable to link it directly because their study was carried at the end of the OLLJ intensity peak and the beginning of the rainy season. Also, Mendez-Espinosa et al. (2019) found a direct link between high $\mathrm{PM}_{2.5}$ and $\mathrm{PM}_{10}$ concentrations in three Colombian Andean cities (i.e., Bucaramanga, Bogotá, and Medellín) and BB emissions originated in the ORIB, demonstrating the long-range transport of BB particles from Venezuela to Colombia.

In the present study, the influence of the longrange transport of $\mathrm{BB}$ emissions in the air quality of the largest city in the Colombian ORIB (i.e., Villavicencio) is evaluated for three consecutive years using online sensors. Additionally, the regional and the trans-boundary impact of the BB events from the ORIB region and the high importance of the OLLJ is assessed by combining model-integrated satellite data and back trajectory analysis.

\section{Methods}

\subsection{Area of study}

Air pollution levels in Villavicencio, Colombia were continuously monitored with two different air quality stations: La Esmeralda (LE) (4 9'4'41'N, 73³8'51'”W) and Catumare (CA) $\left(4^{\circ} 6^{\prime} 28^{\prime \prime} \mathrm{N}, 7^{\circ} 39^{\prime} 19^{\prime \prime} \mathrm{W}, 467 \mathrm{~m}\right.$ a.s.1.). Villavicencio is a middle size city located in the Colombian savannas. The Colombian savannas have a low elevation (200-600 $\mathrm{m}$ a.s.1.) and an extension of ca. $250,000 \mathrm{~km}^{2}$ (Guhl, 2017). This vast region is surrounded by the Andes Mountains to the West, the Venezuelan savannas to the North, and the Guaviare River and the Amazon forest to the South (Goosen, 1971). Warm-humid climate predominates in the region with average annual temperature and relative humidity of $26^{\circ} \mathrm{C}$ and $60 \%$, respectively (Blydenstein, 1967). Most of the annual precipitation $(90 \%)$ falls during the rainy season (i.e., April to December) and contributes significantly to the mean annual accumulated precipitation of $1,500 \mathrm{~mm}$ (Goosen, 1971).
Villavicencio connects the Colombian savannas with the Colombian Andes as it is located in the piedmont of the Andes Mountains, $86 \mathrm{~km}$ away from Bogotá, the capital of Colombia, as shown in Figure 1 . The city has 451,212 inhabitants (DANE, 2019) in $1,328 \mathrm{~km}^{2}$, being the most populated city of the Colombian savannas. It is the main collection and supply center of the region and the Capital of the main gas producer State in Colombia. The city transports $150,000 \mathrm{~m}^{3}$ of gas per day (Cámara de comercio de Villavicencio, 2013) and the Meta State produces 15,000 barrels of petroleum per day in three main extraction fields (Martinez and Delgado, 2018). Agriculture is another important activity of the surrounding $(\sim 20 \mathrm{~km})$ small towns with rice, palm oil, and maize as the main products (Cámara de comercio de Villavicencio, 2013; Alcaldía de Villavicencio, 2016). Also, cattle raising is an important activity of the region that occupies more than $50 \%$ of the productive area (Cámara de comercio de Villavicencio, 2013).

Although there is no detailed emission inventory for Villavicencio, the main emission sources identified for the city include processing food industries, waste incineration, and fuel stations (Parrado, 2020). Additionally, the main mobile emission sources in the city are the private vehicles, mainly motorcycles (Ortíz and Ríos, 2019). The main pollutants identified in the Villavicencio include CO, VOCs, NOx and $\mathrm{PM}_{10}$. It is also important to note that coal is used in several industries as fuel, and therefore, it is responsible for most of the $\mathrm{SO}_{\mathrm{X}}$ emissions reported in the region (Parrado, 2020).

The annual mean precipitation of Villavicencio is $4,383 \mathrm{~mm}$, with an average of $500 \mathrm{~mm} \mathrm{month}^{-1}$ in the rainy season (i.e., April-November) and $100 \mathrm{~mm}$ month $^{-1}$ in the dry season (i.e., December-March) (IDEAM, 2013). The average ambient temperature ranges between $23{ }^{\circ} \mathrm{C}$ and $27{ }^{\circ} \mathrm{C}$, with maximum values of $34^{\circ} \mathrm{C}$ found during the dry season (IDEAM, 2013). The air quality monitoring in Villavicencio begun in October 2017 with the installation of three stations (LE, CA and Cofrem), funded and operated by Cormacarena, the regional environmental agency. Note that only two stations are used in the present study as the data reported by the Cofrem station is not continuous because the station suffered technical issues between November 2017 and March 2020. 


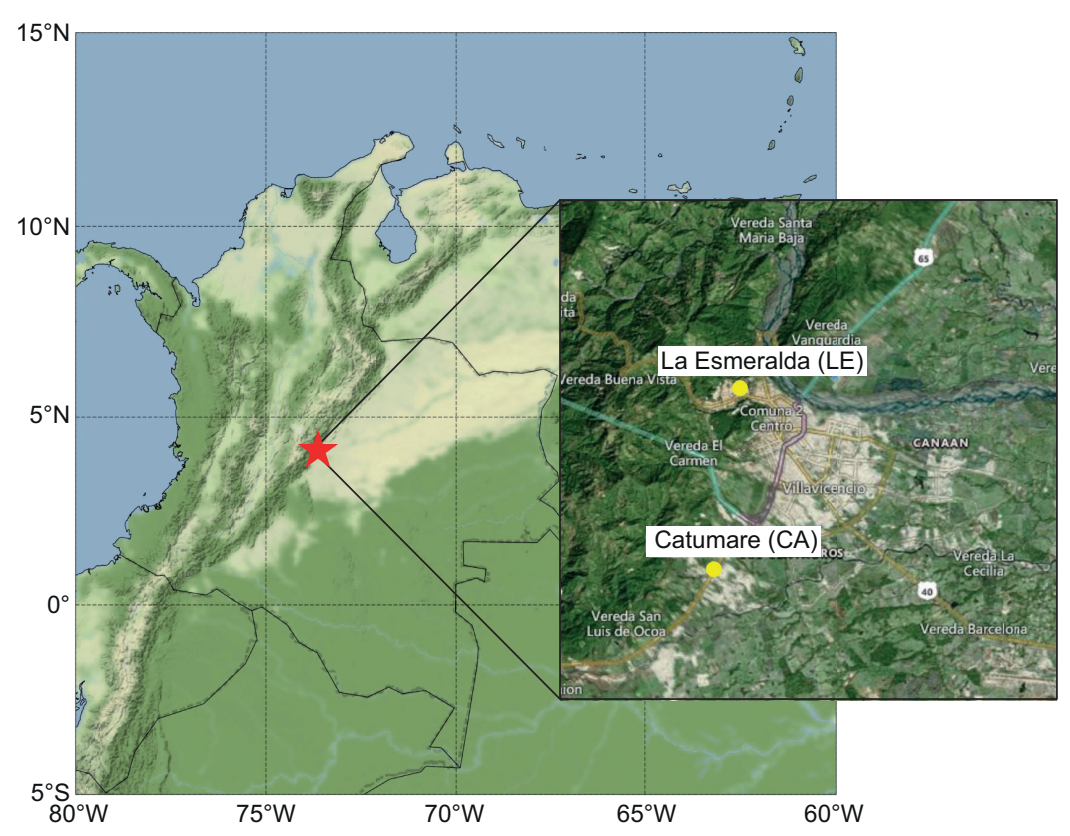

Fig. 1. Map showing the area of study including Villavicencio and the location of the two monitoring stations. The red star represents the location of Villavicencio and the yellow circles indicates the location of La Esmeralda (LE) and Catumare (CA) stations.

\subsection{In-situ air pollutants measurements}

The hourly $\mathrm{PM}_{10}$ and $\mathrm{O}_{3}$ concentrations reported by the LE and CA stations were analyzed from November 2017 to March 2020. Both monitoring stations are located in urban spots, surrounded by houses and roads (Fig. 1). However, the LE station is close to the residual water treatment plant in the suburbs of the city and is expected to measure the background air quality of the city. Meanwhile, the CA station is located nearby the industrial zone of the city and 10 $\mathrm{m}$ away from a busy highway. Although both stations are located in the periphery of the city, they are able to capture the fresh and aged pollutants locally emitted along the day. Moreover, both stations may be sensitive to long-range transported air pollutants arriving to the city.

The $\mathrm{PM}_{10}$ and $\mathrm{O}_{3}$ analyzers used are the MP101M and O342M models from Environment S.A., respectively. The $\mathrm{PM}_{10}$ concentration is measured by the beta ray attenuation technique with continuous measurement at a flow rate of $1 \mathrm{~m}^{3} \mathrm{~h}^{-1}$ (Envea, 2020). Similarly, the operational principle of the $\mathrm{O}_{3}$ detector is based on the UV absorption technique (Envea, 2019). The raw data of both monitoring stations provided by Cormacarena was filtered following the United States Environmental Protection Agency (USEPA, 2017) procedure to delete negative concentrations $\left(<0 \mu \mathrm{g} \mathrm{m}^{-3}\right)$. Also, the EPA filtering criteria for $\mathrm{PM}_{10}$ and $\mathrm{O}_{3}$ data was followed. Abrupt changes in the pollution levels reported by the sampling sensors were detected from time to time after the instrument's shutdown, and therefore, they are not considered in the analysis presented here. It is important to mention that $\mathrm{O}_{3}$ is only measured by the CA station. Also, after the data filtering, only the LE station has valid $\mathrm{PM}_{10}$ data that includes the dry and wet seasons for the analyzed years.

\section{3. $P M_{10}$ composition}

Model products from atmospheric reanalysis is an useful tool to study different variables of interest. The reanalysis products are four-dimensional fields of atmospheric variables that provide continuous spatio-temporal data, in contrast with the in-situ observations that could be sparse (Cohn, 1997; Kalnay, 2003; Schutgens et al., 2010; Rienecker et al., 2011). In this study, the NASA's Global Modeling and Assimilation Office (GMAO) MERRA-2 (The Modern-Era 
Retrospective Analysis for Research and Applications, Version 2) reanalysis was used, as it is the first multi-decadal global reanalysis dataset that combines hyperspectral radiance, microwave data, GPS-Radio occultation data, ozone profile observations, and several other ground and satellite-based datasets, combining aerosol and meteorological variables with their interactions (Randles et al., 2017; Gelaro et al., 2017). The importance of MERRA-2 in this study is that it provides gridded output for aerosol diagnostics parameters not easily observed on a regional scale, with potential applications ranging from air quality forecasting to studies of aerosol-climate interactions (Bocquet et al., 2015; Gelaro et al., 2017).

We used aerosol species concentration from MERRA-2 to estimate monthly regional $\mathrm{PM}_{10}$ (spatial resolution of $0.5^{\circ} \times 0.625^{\circ}$ ) in Villavicencio from the M2I3NVAER database that comprises aerosol mixing ratios for 72 model-level fields on a hybrid-sigma coordinate (GMAO, 2015a). MERRA-2 simulates aerosol species' concentration with the Goddard Chemistry Aerosol Radiation and Transport model (GOCART), which includes bias-corrected aerosol optical depth from NASA Moderate Resolution Imaging Spectroradiometer (MODIS), together with observations from MISR and AERONET (Chin et al., 2002; Provençal et al., 2017). GOCART treats the sources, sinks, and chemistry of 15 externally mixed aerosol mass mixing ratio tracers: dust (DS; five non-interacting size bins), sea salt (SS; five non-interacting size bins), hydrophobic and hydrophilic black and organic carbon (BC and $\mathrm{OC}$, respectively; four tracers), and sulfate ( $\left.\mathrm{SO}_{4}\right)$ (Randles et al., 2017; Buchard et al., 2017). Based on these species concentrations, it is possible to estimate particle total concentration with diameters below $2.5 \mu \mathrm{m}$ and $10 \mu \mathrm{m}$ (Chow et al., 2015). Based on GOCART species sizes, Provençal et al. (2017) proposes an estimate of $\mathrm{PM}_{10}$ by a combination of the tracer's concentrations in $\mu \mathrm{g} \mathrm{m}^{-3}$ given by

$$
\begin{aligned}
& {\left[\mathrm{PM}_{10}\right]=1.375\left[\mathrm{SO}_{4}\right]+1.8[0 \mathrm{C}]+} \\
& {[\mathrm{BC}]+[\mathrm{DS}]+[\mathrm{SS}]}
\end{aligned}
$$

Equation 1 assumes that $\mathrm{SO}_{4}, \mathrm{OC}$, and $\mathrm{BC}$ from GOCART are all in the form of $\mathrm{PM}_{2.5}$ (Buchard et al., 2016, Provençal et al. 2017). $\mathrm{SO}_{4}$ is multiplied by 1.375 since $\mathrm{SO}_{4}$ is assumed to be fully neutralized by ammonium $\left(\mathrm{NH}_{4}\right)$ in the form of ammonium sulfate $\left(\left(\mathrm{NH}_{4}\right)_{2} \mathrm{SO}_{4}\right)$, and $\mathrm{OC}$ is multiplied by 1.8 to account for other organic compounds found in particulate organic matter (Provençal et al. 2017). The contributions from DS and SS are in the range higher than $\mathrm{PM}_{2.5}$ and lower than $\mathrm{PM}_{10}$, since MERRA-2 differentiates these components by particle size (Buchard et al., 2016; Randles et al., 2017; Provençal et al. 2017).

It is important to note that properties of aerosol species are not fully constrained by the observations and are principally determined by the underlying GOCART model (Gelaro et al., 2017). Notwithstanding this fact, MERRA-2 has shown considerable skill in simulating numerous observable aerosol properties worldwide (Buchard et al., 2017) and has been used to estimate $\mathrm{PM}_{10}$ and $\mathrm{PM}_{2.5}$ in Europe, the Middle East, and Asia (e.g, Provençal et al. 2017; Lasko et al. 2018; Song et al., 2018; Xiao et al., 2018; Mahesh et al., 2019; Ukhov et al., 2020; Navinya et al., 2020).

\subsection{The Orinoco low-level jet}

The annual cycle of the mean monthly horizontal winds between 1980 and 2020 was calculated using MERRA-2's M2I3NPASM database (GMAO, 2015b), which gives horizontal winds at different pressure levels. This allows us to estimate the climatological wind patterns in the region and, in particular, the spatio-temporal structure of the OLLJ. To estimate the regional transport of aerosol particles and the influence of the OLLJ, we used the vertical profiles of aerosol mixing ratios from the M2I3NVAER together with horizontal winds (zonal and meridional winds) at each model-level from the M2I3NVASM database (GMAO, 2015c). From basic fluid dynamics, the horizontal flux of a quantity with a mixing ratio $w_{\mathrm{i}}$ at an atmospheric layer of height $\Delta \mathrm{p} / \mathrm{g}$ is given by $\mathrm{wV} \Delta \mathrm{p} / \mathrm{g}$, where $V$ is the horizontal wind vector at the atmospheric layer. Therefore, the vertically integrated horizontal flux of a certain quantity will be given by (Peixoto and Oort, 1992):

$$
Q_{i}=\frac{1}{g} \int_{p 2}^{p 1} w_{i} \vec{V} d p
$$

The horizontal low-level fluxes of OC, DS, and SS were calculated using Equation 2, where $w_{\mathrm{i}}$ is the aerosol mixing ratio for each of the components: $\mathrm{OC}, \mathrm{DS}$, or SS. The integration is performed over the lowest part of the troposphere using 16 S-levels, i.e., approximately the layer between 1000 to $700 \mathrm{hPa}$ in the regions of low topography. 
To support the pollutants source analysis, back trajectories of the air masses arriving in Villavicencio (i.e., to the LE station, Fig. 1) were obtained with the hybrid single-particle lagrangian integrated trajectory (HYSPLIT) model of the National Oceanic and Atmospheric Administration (NOAA). This model uses meteorological data from different sources, such as the National Centers for Environmental Prediction-National Center for Atmospheric Research (NCEP-NCAR) reanalysis model (Stein et al., 2015). 72-hour back trajectories were retrieved for each day at 12:00 and 00:00 LT, between February and April 2018, 2019, and 2020 at $500 \mathrm{~m}$ a.g.l.

\subsection{Biomass Burning activity}

The Biomass Burning activity between 2018 and 2020 was assessed by the burned area inside the ORIB region. This was retrieved using the NASA Fire Information for Resource Management System (NASA FIRMS) through its online Fire Map (https:// firms.modaps.eosdis.nasa.gov/). The FIRMS uses the MODIS global monthly fire location product MCD14ML that detects the burned area with $500 \mathrm{~m}$ MODIS surface reflectance imagery coupled with 1 $\mathrm{km}$ active fire observations from the Terra and Aqua satellites (Giglio et al., 2018). The final product includes the number of fires per month.

\section{Results}

\subsection{Local air pollution sources}

While the LE monitoring station captured the hourly variability of the $\mathrm{PM}_{10}$ concentration in Villavicencio, the CA monitoring station did the same for $\mathrm{O}_{3}$. The available data comprises three dry seasons (December-April) and two wet seasons (May-November), between 2017 and 2020. Figure S1 shows the diurnal cycle of the $\mathrm{PM}_{10}$ and $\mathrm{O}_{3}$ concentrations for the analyzed years, and includes the data of the dry and wet season. The daily average $\mathrm{PM}_{10}$ concentration was found to be $25 \pm 4 \mu \mathrm{g} \mathrm{m}^{-3}$ with the highest average concentration (i.e., $28.0 \mu \mathrm{g} \mathrm{m}^{-3}$ ) observed at ca. 21:00 LT. These overnight high concentrations of $\mathrm{PM}_{10}$ are uncommon in most urban sites and could be related to emissions coming from the surroundings of Villavicencio. Alvarez-Ospina et al. (2021) found that the burning of solid waste can impact the air pollution levels overnight in Merida, Mexico.
This deserves to be further studied to determine the source of the overnight $\mathrm{PM}_{10}$. The $\mathrm{O}_{3}$ daily profile showed a typical behavior for this pollutant with the highest average hourly concentration (i.e., $70.0 \mu \mathrm{g} \mathrm{m}^{-3}$ ) observed at 14:00 LT, which is the time of the day with the highest solar radiation.

Figure 2(a) shows the time series of the monthly $\mathrm{PM}_{10}$ concentrations. A pronounced annual trend in the $\mathrm{PM}_{10}$ concentration was observed with higher concentrations observed between February and April (dry season) with a peak in the $\mathrm{PM}_{10}$ concentration found in March every year. The median $\mathrm{PM}_{10}$ concentration during the dry season is around $40 \mu \mathrm{g}$ $\mathrm{m}^{-3}$, with maximum values of $250 \mu \mathrm{g} \mathrm{m}^{-3}$, observed in March 2020. The lack of $\mathrm{PM}_{10}$ data at the end of 2019 was due to technical reasons. Following the same trends observed for $\mathrm{PM}_{10}$, higher concentrations of $\mathrm{O}_{3}$ were found between December and April, with peak concentrations observed in March every year (Fig. 2b). It is important to note that $\mathrm{O}_{3}$ concentrations only take into account the daylight data (i.e., 06:00-18:00 LT).

The seasonal trends were evaluated to assess the impact of the dry season on the local air quality. As shown in Figure 3, the $\mathrm{PM}_{10}$ and $\mathrm{O}_{3}$ median concentrations are 18 and $21.4 \mu \mathrm{g} \mathrm{m}^{-3}$ higher in the dry season than in the wet season, respectively. Except for the dry season, the pollution levels along the year are below those indicated by the local and international air quality guidelines (Fig. S2). Therefore, this suggests that the high pollution episodes observed in Villavicencio during the dry season could be caused by external sources (see Section 3.2).

In Villavicencio, 12 to $13 \%$ of the days (i.e., 18 19 days) of the dry season exceed the WHO recommendations for $\mathrm{PM}_{10}$ (i.e. $50.0 \mu \mathrm{g} \mathrm{m}^{-3}$ ) and $\mathrm{O}_{3}$ (i.e., $100.0 \mu \mathrm{g} \mathrm{m}^{-3}$ ) concentrations. In contrast, less than two days of the rainy season $(<1 \%)$ exceeds the WHO allowable limits. The Colombian air quality standards set higher allowable limits than the WHO for $\mathrm{PM}_{10}$, i.e., $75.0 \mu \mathrm{g} \mathrm{m}^{-3}$ (Fig. S2). Therefore, throughout the year, less than $2 \%$ of the days exceed the Colombian normative (Fig. S2).

\subsection{Regional air pollution sources}

\subsubsection{Biomass burning over the ORIB}

Every year during the dry season, hundreds of hectares are burned in the ORIB region. Figures 4(a), 




b)

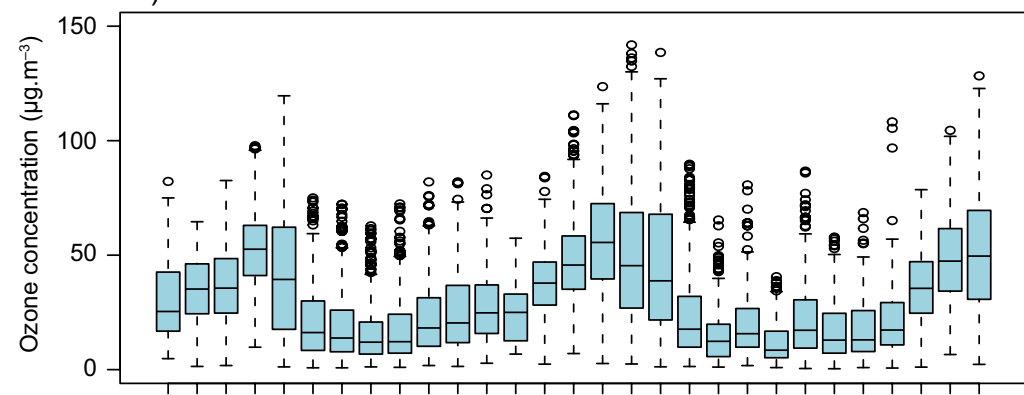

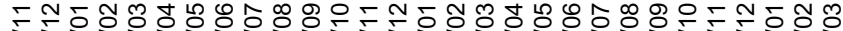

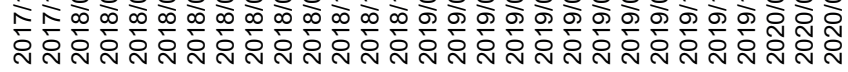

Date

Fig. 2. Time series of the monthly distribution of the hourly concentration of a) $\mathrm{PM}_{10}$ for La Esmeralda station, and, b) $\mathrm{O}_{3}$ from the Catumare station, between November 2017 and March 2020. The top and bottom limits of each box are the 25 th and 75 th percentiles of the monthly concentrations, respectively. The monthly median concentration is represented by the horizontal line in the middle of each box. The top and bottom whiskers on each box indicate the maximum and minimum values, respectively. The open circles indicate outlier values.

(b), and (c) show the location and the density of open fires in the Venezuelan and the Colombian savannas between February and April of 2018, 2019, and 2020, respectively. Figures 4(d) and (e) clearly show that between May and July, BB in the ORIB region is almost absent, in line with an increase in precipitation (Fig. S3). Although open fires were found in large densities in the ORIB region during the 2018 and 2019 dry seasons, in 2018 they were concentrated in the Colombian savannas and in 2019 in the Venezuelan savannas. Even though for 2020 the open fires information is only available for February, a trend similar to that found in the two previous years is observed.

\subsubsection{The OLLJ and the transport of BB pollutants}

Figure 5 shows the annual cycle of mean monthly winds in the layer between $950-800 \mathrm{hPa}$ for the period 1980 2019 estimated from MERRA-2. This figure corresponds to a climatology of the low-level wind patterns in the ORIB region. A particular feature in this climatology is the presence of a low-level jet of northeasterly winds coming from the Atlantic Ocean towards the interior of Colombia, also known as the OLLJ (Montoya et al., 2001; Torrealba and Amador, 2010; Jiménez-Sánchez et al., 2019). As shown in Figure 5, the OLLJ is active between November and March with its highest peak activity found in January with wind speeds higher than $8 \mathrm{~m} \mathrm{~s}^{-1}$, and crossing the entire Colombian ORIB region. 

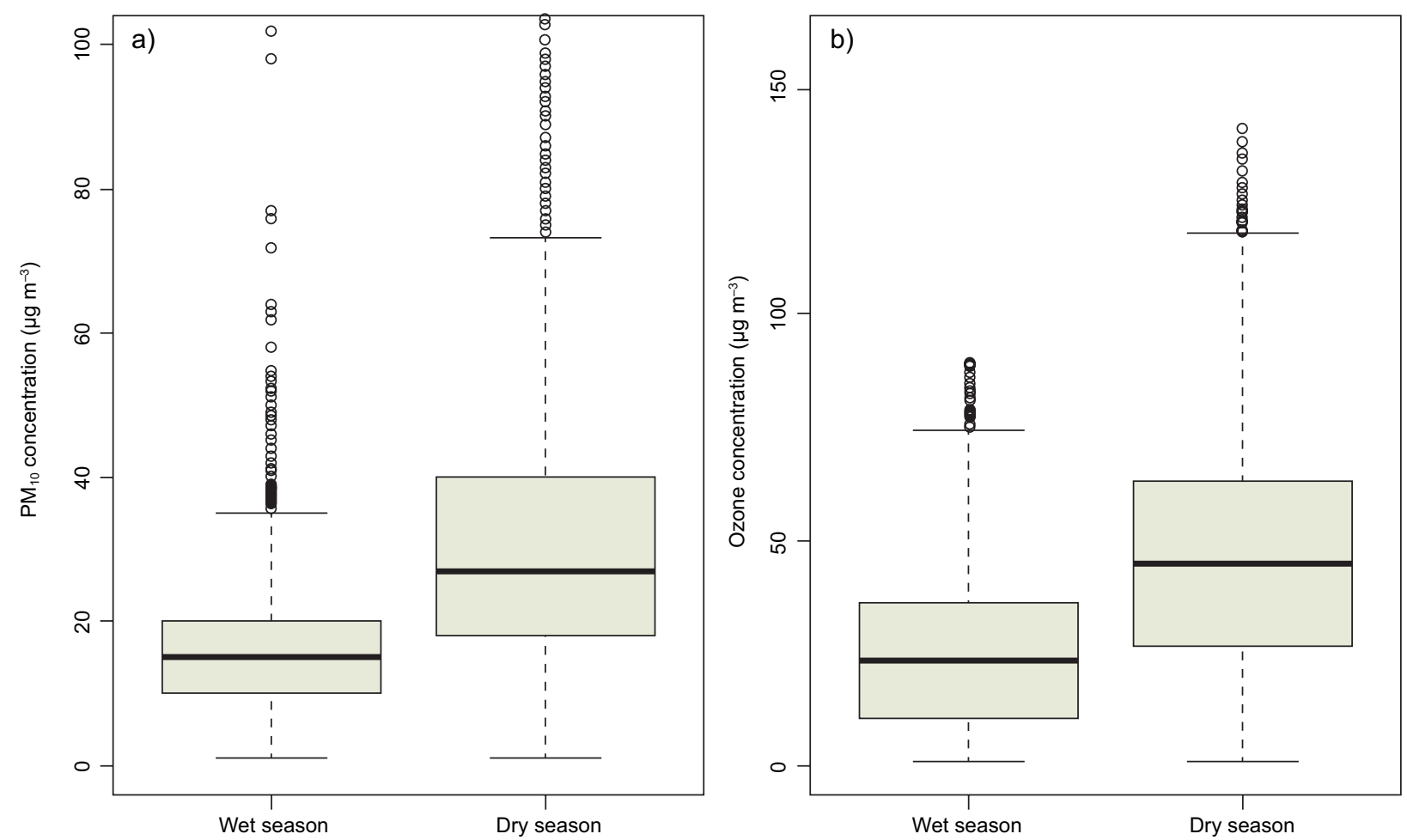

Fig. 3. Intercomparison of the mean hourly concentration of a) $\mathrm{PM}_{10}$ and b) $\mathrm{O}_{3}$ during the rainy and dry seasons for the entire sampling period. The whiskers represent the $5^{\text {th }}$ and the $95^{\text {th }}$ percentile of the $\mathrm{PM}_{10}$ and $\mathrm{O}_{3}$ concentrations.

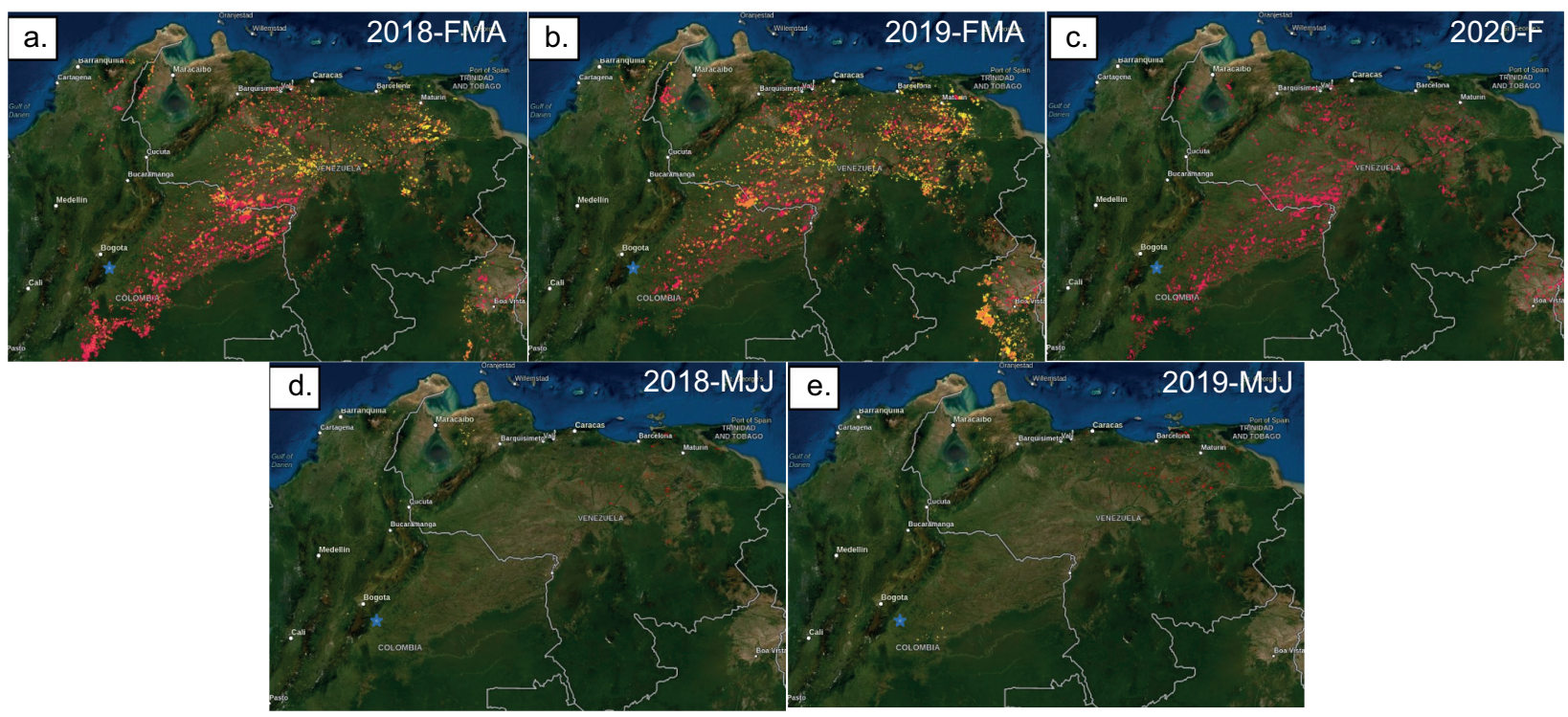

Fig. 4. Schematic representation of the fires in the ORIB region during the dry ( $a, b$, and c) and rainy seasons ( $d$ and e) between 2018 and 2020. The red, orange, and yellow dots correspond to the fires found in February, March, and April, respectively. The green star represents the location of Villavicencio. FMA and MJJ refers to February-March-April and May-June-July, respectively. Retrieved using the NASA Fire Information for Resource Management System (NASA FIRMS). 



Fig. 5. Annual cycle of mean monthly winds in the layer between 950-800 hPa for the period 1980-2019. The lines correspond to streamlines pointing as the wind direction, and color contours correspond to wind speed. The topography is shown for reference as closed contours. Data from MERRA-2. 
Figure $\mathrm{S} 4$ shows a vertical cross-section at $4^{\circ} \mathrm{N}$ from $75^{\circ} \mathrm{W}$ to $61^{\circ} \mathrm{W}$ showing the jet structure that is highly concentrated to the east of the Andes mountain range, in the lowest $4 \mathrm{~km}$, and with a jet center about $1-2 \mathrm{~km}$ a.g.l.

We retrieved HYSPLIT back-trajectories at $500 \mathrm{~m}$ a.g.1 for February-April 2018, 2019, and 2020 as shown in Figure S5. The trajectories show paths consistent with the wind climatology shown in Figure 5, where the prevailing northeasterly winds are due to the presence of the OLLJ. For the three years, air masses consistently arrived at Villavicencio in February from the Atlantic Ocean, crossing the entire ORIB region. The March and April back-trajectories show a weakening of the OLLJ, where the winds have a pronounced easterly origin. However, some April's back-trajectories show a southerly origin, showing an increasing contribution from the Amazon to the region as the ITCZ moves north.
Figures 4 and 5 show an overlap between the OLLJ and the BB activity during the period February-March in the Venezuelan and the Colombian savannas. These figures suggest that the OLLJ can transport BB air pollutants deep into the ORIB region. Additionally, Figure 5 suggests that OLLJ can transport other aerosol particles into the ORIB region, such as marine aerosol and African dust that can affect the air quality in this region. Figure 6 shows the average OC low-level flux given by Equation 2 during the BB season (i.e., February-April) compared with the beginning of the rainy season (i.e., May-July) of 2018 and 2019. Figure 6(a) shows that OC flux is higher than $0.15 \mathrm{~g} \mathrm{~m}^{-1} \mathrm{~s}^{-1}$ along the ORIB region, even reaching the Northeast of Ecuador. Also, Figure 6(b) shows a similar behavior for the 2019 BB season. However, the OC flux is mostly concentrated in the ORIB region with a flow rate higher than $0.25 \mathrm{~g} \mathrm{~m}^{-1} \mathrm{~s}^{-1}$. From
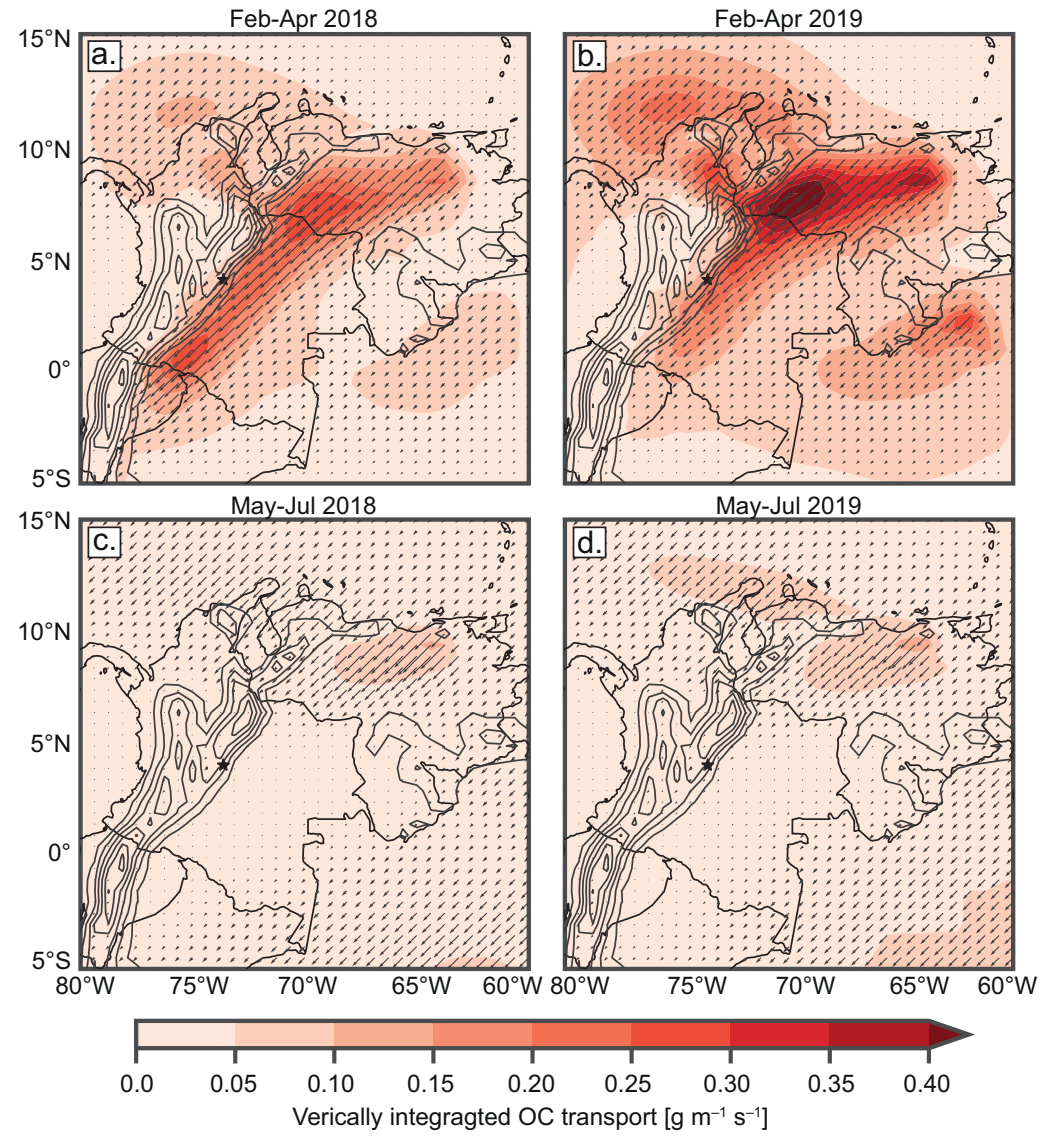

Fig. 6. Map of the northern South America region. Mean OC low-level flux for the period a) February-April 2018, b) February-April 2019, c) May-July 2018, and d) May-July 2019.

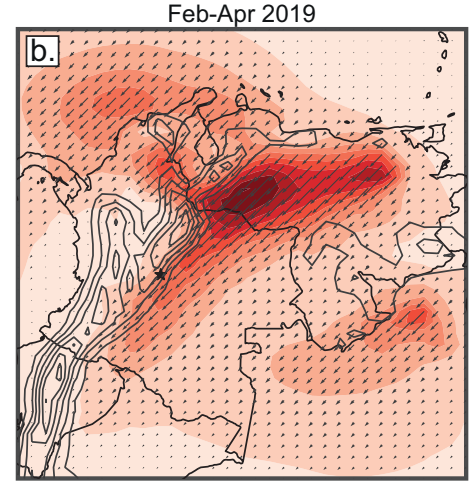


Figures 6(c) and (d), it is evident that at the beginning of the rainy season, in both years, the transport of $\mathrm{OC}$ is absent.

Similar to the OC flux by the OLLJ, fluxes of SS particles from the Atlantic Ocean into the ORIB region were observed (Fig. S6). This SS flux into the ORIB region is intense for the period January-March of 2018 and 2019 but not for the period April-June, suggesting the potentiality of SS transport into the region by the OLLJ. A DS flux into the ORIB region for the period June-August 2018 and 2019 was also observed, which is the period of high levels of African dust that reach the Caribbean and the NSA(Ben-Ami et al., 2010; Prospero et al., 2014; Kishcha et al., 2014), compared with the period September-November 2018 and 2019 (Fig. S7). Figure S7 shows that the trade winds can introduce DS into the continent; however, this intrusion is spatially restricted mostly to the NSA region because the OLLJ is not active during this time of year.

\subsection{3. $P M_{10}$ composition}

In Section 3.2.2 the regional transport of aerosol across the ORIB region was shown, as seen by the estimated low-level aerosol flux with MERRA-2. We evaluated the $\mathrm{PM}_{10}$ composition using Equation 1, to observe the impacts of this transport to the air quality in Villavicencio at the LE station. As we previously mentioned, the aerosol species' concentration properties are principally determined by the underlying GOCART model used by MERRA-2. Therefore we must be cautious with the conclusions from MERRA-2's $\mathrm{PM}_{10}$ estimates. To evaluate how $\mathrm{PM}_{10}$ from MERRA compares with in-situ measurements at the monthly level, we show in Figure 7(a) a comparison of the estimated $\mathrm{PM}_{10}$ with the ground-based observations.
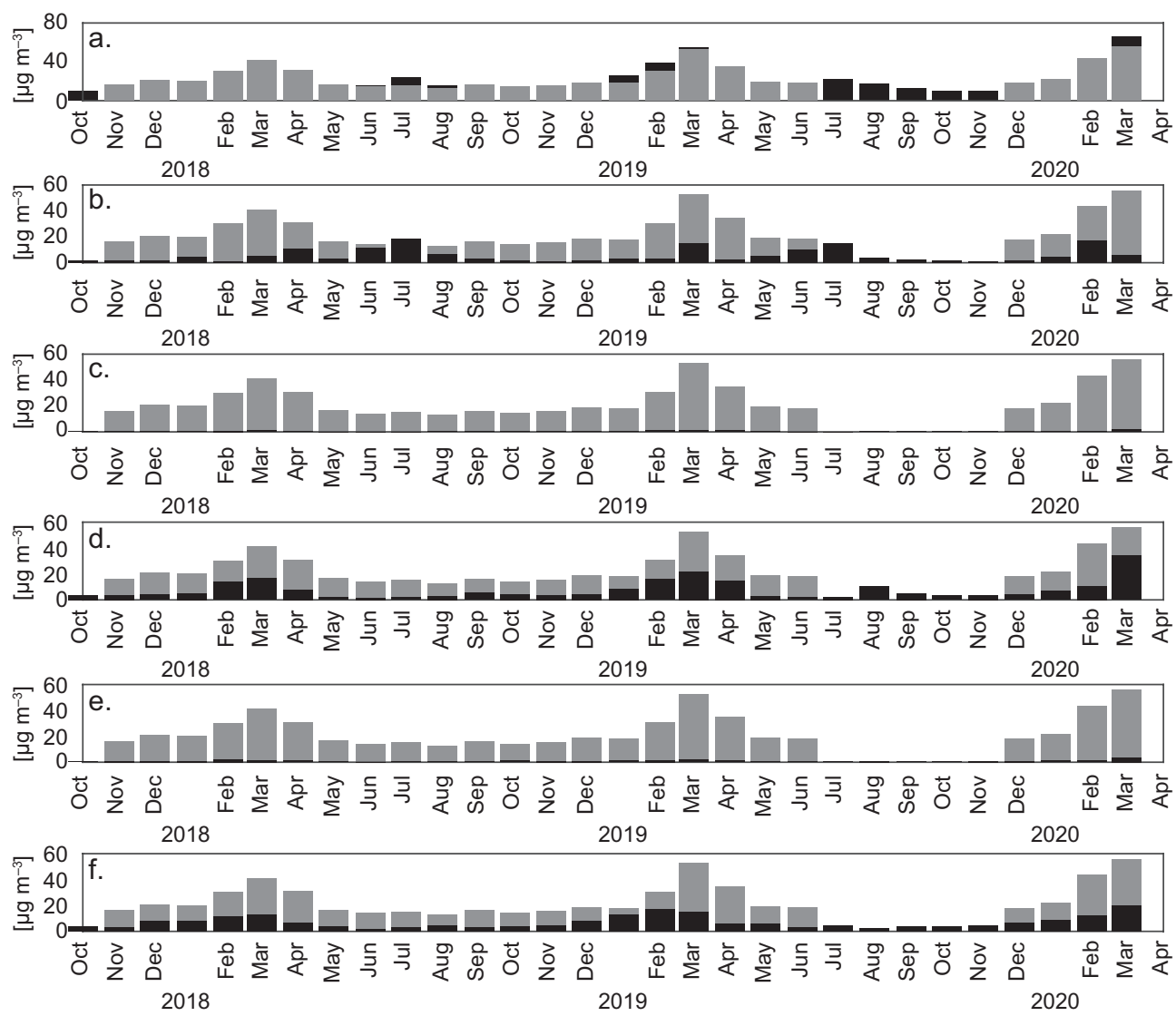

Fig. 7. Time series of the average monthly $\mathrm{PM}_{10}$ at the LE station (grey) compared with a) $\mathrm{PM}_{10}$ estimated from MERRA-2 (black) and with the different components of the Eq. 1 (also in black): b) DS, c) BC, d) OC, e) $\mathrm{SO}_{4}$, and f) $\mathrm{SS}$. 
There is a high agreement between MERRA's estimates and observations. This agreement is clear from the scatter plot of the monthly MERRA-2's PM $_{10}$ vs. ground-based observations in Figure 8, indicating that the monthly $\mathrm{PM}_{10}$ variability was captured adequately by the MERRA-2 reanalysis. This agreement supports the idea that the GOCART component of MERRA is reproducing the PM variability in the region. However, our conclusions should be validated by future field campaigns in the region.

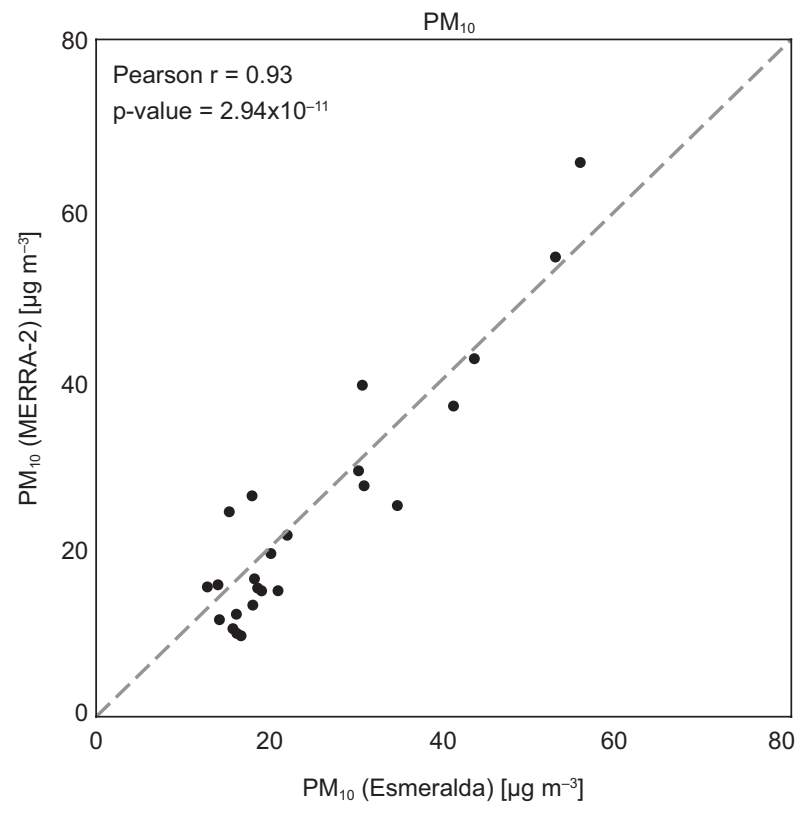

Fig. 8. Scatter plot of monthly MERRA-2's $\mathrm{PM}_{10}$ vs. measured $\mathrm{PM}_{10}$ at LE station.

Figures 7(b), (c), (d), (e) and (f) show the time series of the contribution of each of the aerosol mixing ratios to $\mathrm{PM}_{10}$ as given by Equation 1, against the measured $\mathrm{PM}_{10}$ concentration. It is evident that $\mathrm{BC}$ and $\mathrm{SO}_{4}$ are in very low concentrations (i.e., $<10 \mu \mathrm{g} \mathrm{m}^{-3}$ ) and do not contribute significantly to the $\mathrm{PM}_{10}$ concentration (Figs. 7[c] and 7[e]), suggesting that the air pollution observed in Villavicencio is unlikely to be originated by local sources.

In contrast to $\mathrm{BC}$ and $\mathrm{SO}_{4}$, the $\mathrm{DS}, \mathrm{OC}$, and $\mathrm{SS}$ concentrations were found to be important contributors to the $\mathrm{PM}_{10}$ in Villavicencio. While DS was found to report high concentrations around April and during the July-August period with the highest mixing ratio of $65.0 \mu \mathrm{g} \mathrm{m}^{-3}$ found in July 2018 (Fig. 7[b]); the SS and OC were found in higher concentrations during the dry season (i.e., December-April) with concentrations higher than $20 \mu \mathrm{g} \mathrm{m}^{-3}$. As shown in Figure 7(d), the estimated OC mixing ratio nicely follows the measured $\mathrm{PM}_{10}$ concentrations trend in all three dry seasons.

\section{Discussion}

The continuous monitoring of $\mathrm{PM}_{10}$ and $\mathrm{O}_{3}$ in Villavicencio was useful to evaluate air quality in this city and to corroborate that every year during the dry season air quality deteriorates coinciding with the BB season and the OLLJ activity. It is important to note that this is the first, continuous, and high temporal resolution monitoring system implemented in the Colombian savannas that covers four states and a total extension of $250,000 \mathrm{~km}^{2}$. The good air quality that the city experiences most of the year (i.e., average annual $\mathrm{PM}_{10}$ concentration of $15 \mu \mathrm{g} \mathrm{m}^{-3}$ and $\mathrm{O}_{3}$ concentration of $21 \mu \mathrm{g} \mathrm{m}^{-3}$ for the entire sampling period) can be explained by the relative low road traffic, the scarce industrial development, the relatively low population (ca. 500,000 inhabitants), and the flat terrain. The $\mathrm{PM}_{10}$ and $\mathrm{O}_{3}$ concentrations in two similar cities in the ORIB region, i.e., Yopal and Arauca, during the rainy season (considered as the baseline) were found to be three times higher than in Villavicencio (Hernandez et al., 2019). This difference could be explained in part by the higher precipitation rate reported in Villavicencio during the rainy season (i.e., a monthly average of $380 \mathrm{~mm}$ [IDEAM, 2013]) compared to the other two cities for the same period. While Arauca reports monthly average precipitation of $198 \mathrm{~mm}$ (IDEAM, 2000), the average precipitation rate for Yopal is $287 \mathrm{~mm}$ per month (IDEAM, 2012).

Opposite to the rainy season, the $\mathrm{PM}_{10}$ concentrations found in April in Villavicencio (i.e., close or above $50 \mu \mathrm{g} \mathrm{m}^{-3}$ ) were found to be comparable with the concentrations reported in Yopal and Arauca (i.e., $53 \mu \mathrm{g} \mathrm{m}^{-3}$ on average) for the same period (Hernandez et al., 2019). In all three cities, $\mathrm{PM}_{10}$ peak concentrations close to $100 \mu \mathrm{g} \mathrm{m}^{-3}$ were occasionally observed in April. The similarities in the $\mathrm{PM}_{10}$ levels of Villavicencio, Arauca, and Yopal during the dry season are indicative that there is an external source 
of air pollution that affects the cities located along the ORIB region.

The $\mathrm{PM}_{10}$ composition of Villavicencio assessed through the MERRA-2 reanalysis products was useful to understand the role of the local vs. the external air pollution sources. The relatively low concentrations of $\mathrm{SO}_{4}$ and $\mathrm{BC}$ (i.e., less than $10 \mu \mathrm{g} \mathrm{m}^{-3}$ ) found between 2017 and 2020 are indicative that local sources are not the main contributors to the $\mathrm{PM}_{10}$ levels measured at the LE monitoring station, mainly in the dry season. As shown by several studies, $\mathrm{SO}_{4}$ and $\mathrm{BC}$ emissions are highly related to urban pollution, industrial activities, and road traffic emissions (Subramanian et al., 2010; Invernizzi et al., 2011; Srimuruganandam and Shiva Nagendra, 2011; Xu et al., 2012; Yin et al., 2012; Pereira et al., 2012; Lee and Hieu, 2013; Han et al., 2014; Targino et al., 2016).

In contrast to the rainy season, high concentrations of $\mathrm{PM}_{10}$ and $\mathrm{O}_{3}$ were found during the dry season, specifically between February and April. Figure 4 shows a large number of open fires in the ORIB region between February and April, in contrast to the rainy season (May-July) when open fires are mostly absent. The BB season fires from the Venezuelan and the Colombian savannas can negatively impact the air quality of different Colombian towns as shown before (Hernandez et al., 2019; Mendez-Espinosa et al., 2019). The climatology of the low-level wind patterns in the ORIB region clearly shows that the OLLJ is active between November and March (Fig. 5). Also, Figure 6 shows that there is an effective OC flux along the ORIB region during the $\mathrm{BB}$ season. The high OC concentrations found between February and April are related to BB particles transported across the ORIB region when the OLLJ intensifies (Figs. 5 and 6). Figure 7 shows a good relationship between the $\mathrm{PM}_{10}$ and the $\mathrm{OC}$ concentrations, indicating that the seasonal pollution levels observed in Villavicencio could be driven by the BB season in the ORIB region. Previous studies found that more than half of the particle mass of the $\mathrm{BB}$ emissions is classified as OC (Reid et al., 2005).

In summary, as shown in Figures 4, 5, and 6, the high pollution levels found in Villavicencio are likely related to the $\mathrm{BB}$ emissions from the Venezuelan and the Colombian savannas transported across the ORIB region by the OLLJ. Although the OLLJ was previously identified and studied through numerical modeling (Jiménez-Sánchez et al., 2019), ground base data (Torrealba and Amador, 2010), and reanalysis (Montoya et al., 2001), this is the first time that its climatological behavior and its impact in the transport of air pollutants is analyzed. As shown in Figures S6 and S7, besides OC, the OLLJ can transport biogenic aerosol particles such as African dust and SS from the Atlantic Ocean to Venezuela and the central-southern part of Colombia. Mineral dust can be transported by the trade winds coming from the African deserts towards the Caribbean and the NSA (Formenti et al., 2001; Prospero et al., 2014; Kishcha et al., 2014; Méndez et al., 2018). Those particles also have the potential to affect the air quality in Villavicencio and likely in the entire ORIB region (Fig. 7). The HYSPLIT back trajectories support the likelihood of effective transport of pollutants by the OLLJ from the Atlantic Ocean, and the Venezuela and the Colombian savannas towards Villavicencio and other cities along with the Andes mountains range.

\section{Conclusions}

Although Villavicencio is a medium-size town with no large-scale industrial activities, the local air quality was found to be poor during the dry season (i.e., February to April) with $\mathrm{PM}_{10}$ levels (i.e., $100 \mu \mathrm{g} \mathrm{m}^{-3}$ ) above the national and $\mathrm{WHO}$ guidelines, i.e., $75 \mu \mathrm{g} \mathrm{m}^{-3}$ and $50 \mu \mathrm{g} \mathrm{m}^{-3}$, respectively. Given that the likely source of the high $\mathrm{PM}_{10}$ levels found in Villavicencio is the $\mathrm{BB}$ events that occur in the Venezuelan and the Colombian savannas, the situation can be even worse if $\mathrm{PM}_{2.5}$ is monitored as they have a higher residence time.

The present results suggest that African dust and SS particles can potentially impact both the local and the regional air quality of the medium-sized towns located along the ORIB. The transport of the air pollutants generated by BB in the Colombian/ Venezuelan savannas, together with SS particles and African dust towards these towns, is favored by the presence of the OLLJ. Besides the risk that the OLLJ represents for aviation safety in the ORIB region (Jiménez-Sánchez et al., 2019), the present study provides clear evidence that the OLLJ is a key driver in determining the air quality across the ORIB region. Also, our study suggests that in some 
cases, the OLLJ can transport air pollutants from the Atlantic Ocean, Venezuela, and Colombia to Ecuador. This needs to be confirmed by ground-based observations either in the southwest of Colombia or Northern Ecuador.

As shown in previous studies, BB emissions does not only have the potential to affect people living in populated towns, as they can also affect the flora and fauna of natural protected areas (e.g., Trujano Jiménez et al., 2021). Therefore, based on the results from the present study, several natural protected areas from Colombia such as Serrania de la Macarena, Parque Nacional Cueva de los Guachos, Parque Nacional Natural La Paya, and the Northern Amazon can be in danger by the combination of the BB emissions from the Venezuelan/Colombian savannas and the OLLJ.

There is an urgent need to improve the current understanding of the local and regional impacts of the long-range transport of $\mathrm{BB}$ emissions from Venezuela to Colombia to coordinate international collaborations to mitigate this problem. Therefore, the implementation of real-time air quality sensors in the Arauca, Yopal, Meta, and Putumayo states are recommended. The delivered data will be useful for policy makers to develop different programs to reduce fires density, and hence, the air pollution levels along the ORIB region.

\section{Acknowledgments}

The authors thank to Victor Bravo, Jorge Ladino, and Juan Niño of the local environmental agency Cormacarena for collecting and sharing the groundbased data. The authors also thank to the National Oceanic and Atmospheric Administration (NOAA) for the HYSPLIT model usage, the National Aeronautics and Space Administration (NASA) for the MERRA-2 reanalysis data and the access to the NASA FIRMS application to download the data shown here, and the IDEAM (area operativa No 03) for the meteorological data.

\section{Data availability}

Data is available in SISAIRE-IDEAM web page http://sisaire.ideam.gov.co/ideam-sisaire-web/ and it is updated every six months IDEAM (2019).

\section{References}

Adame JA, Hernández-Ceballos MA, Bolívar JP, and De la Morena B. 2012. Assessment of an air pollution event in the southwestern Iberian Peninsula, Atmospheric Environment 55: 245-256. https://doi.org/10.1016/j. atmosenv.2012.03.010

Alcaldía de Villavicencio. 2016. Economía. Available at http://www.villavicencio.gov.co/MiMunicipio/ (accessed 2020 March 15)

Alvarez-Ospina H, Giordano S, Ladino LA, Raga GB, Muñoz-Salazar J, Leyte-Lugo M, Rosas D, and Carabali G. 2021. Particle-bound polycyclic aromatic hydrocarbons (pPAHs) in Merida, Mexico. Aerosol and Air Quality Research 21: 200245. https://doi. org/10.4209/aaqr.200245

Andreae MO, and Merlet P. 2001. Emission of trace gases and aerosols from biomass burning. Global Biogeochemical Cycles 15: 955-966. https://doi. org/10.1029/2000GB001382

Armenteras-Pascual D, Retana-Alumbreros J, MolownyHoras R, Roman-Cuesta R.M, Gonzalez-Alonso F, and Morales-Rivas M. 2011. Characterizing fire spatial pattern interactions with climate and vegetation in Colombia. Agricultural and Forest Meteorology 151:279289. https://doi.org/10.1016/j.agrformet.2010.11.002

Arsht A. 2013. Urbanization in Latin America. Available at https://www.atlanticcouncil.org/commentary/article/ urbanization-in-latin-america/ (accessed 2020 March 20)

Aurell J, and Gullett BK. 2013. Emission factors from aerial and ground measurements of field and laboratory forest burns in the southeastern U.S.: PM2.5, black and brown carbon, VOC, and PCDD/PCDF. Environmental Science and Technology, 47(15), 8443-8452. https:// doi.org/10.1021/es402101k

Ben-Ami Y, Koren I, Rudich Y, Artaxo P, Martin ST, and Andreae MO. 2010. Transport of North African dust from the Bodélé depression to the Amazon Basin: A case study. Atmospheric Chemistry and Physics 10: 7533-7544. https://doi.org/10.5194/acp-10-7533-2010

Bergin MS, West JJ, Keating TJ, and Russell AG. 2005. Regional atmospheric pollution and transboundary air quality management. Annual Review of Environment and Resources 30: 1-37. https://doi.org/10.1146/annurev.energy.30.050504.144138

Blydenstein J. 1967. Tropical savanna vegetation of the Llanos of Colombia. Ecology 48: 1-15. https://doi. org/10.2307/1933412 
Bocquet M, Elbern H, Eskes H, Hirtl M, Žabkar R, Carmichael G, Flemming J, Inness A, Pagowski M, Camaño J, Saide P, Jose R, Sofiev M, Vira J, Baklanov A, Carnevale C, Grell G, and Seigneur C. 2015. Data assimilation in atmospheric chemistry models: current status and future prospects for coupled chemistry meteorology models. Atmospheric Chemistry and Physics 15: 5325-5358. https://doi.org/10.5194/ acp-15-5325-2015

Buchard V, Randles C, Silva A, Darmenov A, Colarco P, Govindaraju R, Ferrare R, Hair J, Beyersdorf A, Ziemba L, and Yu H. 2017. The MERRA-2 Aerosol Reanalysis, 1980 Onward. Part II: Evaluation and Case Studies. Journal of Climate 30: 6851-6872. https://doi. org/10.1175/jcli-d-16-0613.1

Cachier H, Liousse C, Buat-Menard P, and Gaudichet A. 1995. Particulate content of savanna fire emissions. Journal of Atmospheric Chemistry 22: 123-148. https://doi.org/10.1007/BF00708185

Cámara de comercio de Villavicencio. 2013. Caracterización tejido empresarial Villavicencio. Available at https://expeditiorepositorio.utadeo.edu.co/handle/20.500.12010/1978 (accessed 2020 March 01)

Castro Videla F, Barnaba F, Angelini F, Cremades P, and Gobbi GP. 2013. The relative role of Amazonian and non-Amazonian fires in building up the aerosol optical depth in South America: A five year study (2005-2009). Atmospheric Research 122: 298-309. https://doi. org/10.1016/j.atmosres.2012.10.026

Chin M, Ginoux P, Kinne S, Torres O, Holben B, Duncan B, Martin R, Logan J, Higurashi A, and Nakajima T. 2002. Tropospheric Aerosol Optical Thickness from the GOCART Model and Comparisons with Satellite and Sun Photometer Measurements. Journal of the Atmospheric Sciences 59: 461-483. https://doi.org/ 10.1175/1520-0469(2002)059<0461:TAOTFT $>2.0$. $\mathrm{CO} ; 2$

Chow JC, Lowenthal DH, Chen LA, Wang X, and Watson JG. 2015. Mass reconstruction methods for PM2.5: a review. Air Quality, Atmosphere \& Health 8: 243-263. https://doi.org/10.1007/s11869-015-0338-3

Cohn SE. 1997. An Introduction to Estimation Theory. Journal of Meteorological Society of Japan 75(1B): 257-288.

Cordeiro RC, Turcq B, Moreira LS, Rodrigues RAR, Lamego Simões Filho FF, Martins GS, Santos AB, Barbosa M, Guilles daConcei ç ao MC, Rodrigues RC, Evangelista H, Moreira-Turcq P, Penido YP, Sifeddine
A, and Seoane JCS. 2014. Palaeofires in Amazon: Interplay between land use change and palaeoclimatic events. Palaeogeography, Palaeoclimatology, Palaeoecology 415: 137-151. https://doi.org/10.1016/j. palaeo.2014.07.020

Cottle P, Strawbridge K, and McKendry I. 2014. Longrange transport of Siberian wild-fire smoke to British Columbia: Lidar observations and air quality impacts. Atmospheric Environment 90: 71-77. https://doi. org/10.1016/j.atmosenv.2014.03.005

Cuchiara GC, Rappenglück B, Rubio MA, Lissi E, Gramsch E, and Garreaud RD. 2017. Modeling study of biomass burning plumes and their impact on urban air quality: a case study of Santiago de Chile. Atmospheric Environment 166: 79-91. https://doi.org/10.1016/j. atmosenv.2017.07.002

DANE 2019. Viviendas, Hogares y Personas (VIHOPE). Available at https://dane.maps.arcgis.com/ apps/MapSeries/index.html?appid $=\mathrm{e} 53 \mathrm{e} 1178 \mathrm{fb} 1 \mathrm{f}$ 497cac9b241dbafb1690 (accessed 2020 February 20)

Dignon J. 1992. NOx and SOx emissions from fossil fuels: A global distribution. Atmospheric Environment 26: 1157-1163. https://doi.org/10.1016/09601686(92)90047-O

Donnelly AA, Broderick BM, and Misstear BD. 2015. Toxic / Hazardous Substances and Environmental Engineering. The effect of long-range air mass transport pathways on PM10 and NO2 concentrations at urban and rural background sites in Ireland: Quantification using clustering techniques, Journal of Environmental Science and Health Part A 50: 647-658. https://doi.or $\mathrm{g} / 10.1080 / 10934529.2015 .1011955$

dos Santos LH, Kerr AA, Veríssimo TG, Andrade MF, de Miranda RM, Fornaro A, and Saldiva P. 2014. Analysis of atmospheric aerosol (PM2.5) in Recife city, Brazil. Journal of the Air \& Waste Management Association 64: 519-528. https://doi.org/10.1080/10962247.201 3.854282

Duan F, Liu X, Yu T, and Cachier H. 2004. Identification and estimate of biomass burning contribution to the urban aerosol organic carbon concentrations in Beijing. Atmospheric Environment 38: 1275-1282. https://doi. org/10.1016/j.atmosenv.2003.11.037

Dwyer E, Pinnock S, Gregoire JM, and Pereira JM. 2000. Global spatial and temporal distribution of vegetation fire as determined from satellite observations. International Journal of Remote Sensing 21: 1289-1302. https://doi.org/10.1080/014311600210182 
Envea. 2019. O342M. Ozone analyzer. Available at http://www.environnement-sa.com/products-page/ en/o342m-ozone-analyzer/ (accessed 2020 March 28) LINK NOT FOUND

Envea. 2020. MP101M, PM10, PM2.5 and PM1 fine dust monitor. Available at https://www.envea.global/s/ambient-en/particulate-monitors-ambient-en/mp101m/ (accessed 2020 March 28)

Formenti P, Andreae MO, Lange L, Roberts G, Cafmeyer J, Rajta I, Maenhaut W, Holben BN, Artaxo P, and Lelieveld J. 2001. Saharan dust in Brazil and Suriname during the Large-Scale Biosphere-Atmosphere Experiment in Amazonia (LBA) - Cooperative LBA Regional Experiment (CLAIRE) in March 1998. Journal of Geophysical Research 106: 14919-14934. https://doi.org/10.1029/2000JD900827

Garcia-Hurtado E, Pey J, Borrás E, Sánchez P, Vera T, Carratalá A, Alastuey A, Querol X, and Vallejo VR. 2014. Atmospheric PM and volatile organic compounds released from Mediterranean shrubland wildfires. Atmospheric Environment 89: 85-92. https://doi. org/10.1016/j.atmosenv.2014.02.016

Gelaro R, McCarty W, Suárez M J, Todling R, Molod A, Takacs L, Randles CA, Darmenov A, Bosilovich MG, Reichle R, Wargan K, Coy L, Cullather R, Draper C, Akella S, Buchard V, Conaty A, Silva AM, Gu W, Kim G-K, Koster R, Lucchesi R, Merkova D, Nielsen JE, Partyka G, Pawson S, Putman W, Rienecker M, Schubert SDF, Sienkiewicz M, and Zhao B. 2017. The Modern-Era Retrospective Analysis for Research and Applications, Version 2 (MERRA-2). Journal of Climate 30: 5419-5454. https://doi.org/10.1175/ jcli-d-16-0758.1

Giglio L, Boschetti L, Roy DP, Humber ML, and Justice CO. 2018. The Collection 6 MODIS burned area mapping algorithm and product. Remote Sensing of Environment 217: 72-85. https://doi.org/10.1016/j. rse.2018.08.005

GMAO.2015a. MERRA-2 inst3_3d_aer_Nv: 3d, 3-Hourly, Instantaneous, Model-Level, Assimilation, Aerosol Mixing Ratio V5.12.4. https://doi.org/10.5067/LTVB4GPCOTK2

GMAO. 2015b. MERRA-2 inst3_3d_asm_Np: 3d, 3-Hourly, Instantaneous, Pressure-Level, Assimilation, Assimilated Meteorological Fields V5.12.4. https://doi. org/10.5067/QBZ6MG944HW0

GMAO. 2015c. MERRA-2 inst3_3d_asm_Nv: 3d, 3-Hourly, Instantaneous, Model-Level, Assimilation,
Assimilated Meteorological Fields V5.12.4. https:// doi.org/10.5067/WWQSXQ8IVFW8

Goosen D. 1971. Physiography and soils of the Llanos Orientales, Geoderma 9: 151-153.

Guhl E. 2017. Colombia bosquejo de su geografía tropical Vol II Geografía Humana. Ediciones Uniandes-Universidad de los Andes. Available at https://ediciones. uniandes.edu.co/Paginas/Noticias.aspx?nid=43 (accessed 2020 February 01)

Hamburger T, Matisans M, Tunved P, Strom J, Calderon S, Hoffmann P, Hochschild G, Gross J, Schmeissner T, Wiedensohler A, and Krejci R. 2013. Long-term in situ observations of biomass burning aerosol at a high altitude station in Venezuela- Sources, impacts and interannual variability. Atmospheric Chemistry and Physics 13: 9837-9853. https://doi.org/10.5194/ acp-13-9837-2013

Han T, Liu X, Zhang Y, Gu J, Tian H, Zeng L, Chang SY, Cheng Y, Lu K, and Hu M. 2014. Chemical characteristics of PM10 during the summer in the mega-city Guangzhou, China. Atmospheric Research 137: 25-34. https://doi.org/10.1016/j.atmosres.2013.10.004

Hernandez AJ, Morales-Rincon LA, Wu D, Mallia D, Lin JC, and Jimenez R. 2019. Transboundary transport of biomass burning aerosols and photochemical pollution in the Orinoco River Basin. Atmospheric Environment 205; 1-8. https://doi.org/10.1016/j.atmosenv.2019.01.051

IDEAM. 2000. Arauca- Información aeronáutica. Available at http://bart.ideam.gov.co/cliciu/arauca/precipitacion.htm (accessed 2020 March 01)

IDEAM. 2012. Yopal- Información Aeronáutica. Available at http://bart.ideam.gov.co/cliciu/yopal/precipitacion. htm (accessed 2020 March 01)

IDEAM. 2013. Climatología aeronáutica. Aeródromo Vanguardia SKVV - Villavicencio. Available at http:// www.ideam.gov.co/documents/290086/75945771/ SKVV/f58df908-45a5-4397-a56d-589f07926058 (accessed 2020 March 01)

IDEAM. 2019. SISAIRE-Villavicencio. Available at http:// sisaire.ideam.gov.co/ideam-sisaire-web/calidad_aire estaciones.xhtml?tipo $=$ mun\&id $=50001($ accessed 2020 March 01) NOT CITED IN TEXT

Invernizzi G, Ruprecht A, Mazza R, De Marco C, Močnik G, Sioutas C, and Westerdahl D. 2011. Measurement of black carbon concentration as an indicator of air quality benefits of traffic restriction policies within the ecopass zone in Milan, Italy. Atmospheric 
Environment 45: 3522-3527. https://doi.org/10.1016/j. atmosenv.2011.04.008

Jaffe DA, and Wigder NL. 2012. Ozone production from wildfires: A critical review. Atmospheric Environment 51: 1-10. https://doi.org/10.1016/j.atmosenv.2011.11.063

Jiménez-Sánchez, G., Markowski, P. M., Jewtoukoff, V., Young, G. S., and Stensrud, D. J. 2019. The Orinoco Low-Level Jet: An Investigation of Its Characteristics and Evolution Using the WRF Model. Journal of Geophysical Research 124: 10696-10711. https://doi. org/10.1029/2019JD030934

Kalnay E. 2003. Atmospheric modeling, data assimilation and predictability. Cambridge University press. https:// doi.org/10.1017/CBO9780511802270

Kishcha P, da Silva AM, Starobinets B, Long CN, Kalashnikova O, and Alpert P. 2014. Meridional distribution of aerosol optical thickness over the tropical Atlantic Ocean. Atmospheric Chemistry and Physics Discussions 14: 23309-23339. https://doi.org/10.5194/acpd14-23309-2014

Koch D, Bond TC, Streets D, Unger N, and van der Werf GR. 2007. Global impacts of aerosols from particular source regions and sectors. Journal of Geophysical Research Atmospheres112: D02205 . https://doi. org/10.1029/2005JD007024

Kollanus V, Tiittanen P, Niemi JV, and Lanki T. 2016. Effects of long-range transported air pollution from vegetation fires on daily mortality and hospital admissions in the Helsinki metropolitan area, Finland. Environmental Research 151: 351-358. https://doi. org/10.1016/j.envres.2016.08.003

Lasko K, Vadrevu K, Nguyen T. 2018. Analysis of air pollution over Hanoi, Vietnam using multi-satellite and MERRA reanalysis datasets. PLoS One 13: e0196629. https://doi.org/10.1371/journal.pone.0196629

Lee BK, and Hieu NT. 2013. Seasonal ion characteristics of fine and coarse particles from an urban residential area in a typical industrial city. Atmospheric Research 122: 362-377. https://doi.org/10.1016/j. atmosres.2012.12.003

Mahesh B, Rama B, Spandana B, Sarma M, Niranjan K, and Sreekanth V. 2019. Evaluation of MERRAero PM2.5 over Indian cities. Advances in Space Research 64: 328-334. https://doi.org/10.1016/j. asr.2019.04.026

Marín JC, Raga GB, Arévalo J, Baumgardner D, Córdova AM, Pozo D, Calvo A, Castro A, Fraile R, and
Sorribas M. 2017. Properties of particulate pollution in the port city of Valparaiso, Chile. Atmospheric Environment 171:301-316. https://doi.org/10.1016/j. atmosenv.2017.09.044

Martinez A, and Delgado M. 2018. Estudio sobre el impacto de la actividad petrolera en las regiones productoras de Colombia. Caracterización departamental Meta. Available at https://www.repository. fedesarrollo.org.co/handle/11445/3618 (accessed 2020 March 15)

McDonald, B. C., De Gouw, J. A., Gilman, J. B., Jathar, S. H., Akherati, A.,Cappa, C. D., Jimenez JL, Lee-Taylor J, Hayes PL, McKeen SA, Cui YY, Kim SW, Gentner DR, Isaacman-VanWertz G, Goldstein AH, Harley RA, Frost GJ, Roberts JM, Ryerson TB, and Trainer M. 2018. Volatile chemical products emerging as largest petrochemical source of urban organic emissions. Science 359: 760-764. https://doi.org/10.1126/ science.aaq0524

Méndez JF, Pinto Herrera LC, and Belalcázar-Cerón LC. 2018. Estudio de una intrusión de polvo sahariano en la atmósfera de Colombia. Revista Ingenierías Universidad de Medellín 17: 17-34. https://doi.org/10.22395/ rium.v17n32a1

Mendez-Espinosa JF, Belalcazar LC, and Morales-Betancourt R. 2019. Regional air quality impact of northern South America biomass burning emissions. Atmospheric Environment 203: 131-140. https://doi. org/10.1016/j.atmosenv.2019.01.042

Montoya GJ, Pelkowski J, and Eslava J. 2001. Sobre los alisios del nordeste y la existencia de una corriente en el piedemonte oriental Andino. Revista de la Academia Colombiana de Ciencias Exactas, Fisicas y Naturales 25: 363+. Available at https://go.gale.com/ps/anonymous?id=GALE\%7CA498583713\&sid=googleScholar\&v=2.1\&it=r\&linkaccess $=$ abs\&issn $=03703908 \& p=$ IFME $\&$ sw $=w$

Navinya C, Vinoj V, and Pandey S. 2020. Evaluation of PM2.5 Surface Concentrations Simulated by NASA's MERRA Version 2 Aerosol Reanalysis over India and its Relation to the Air Quality Index. Aerosol and Air Quality Research 20: 1329-1339. https://doi. org/10.4209/aaqr.2019.12.0615

Oliveira BFA, Ignotti E, and Hacon SS. 2011. A systematic review of the physical and chemical characteristics of pollutants from biomass burning and combustion of fossil fuels and health effects in Brazil. Cadernos de Saúde Pública 27: 1678-1698. https://doi.org/10.1590/ s0102-311x2011000900003 
Ortíz NF and Ríos JA. 2019. Inventario preliminar de emisiones por fuentes móviles en ruta para la ciudad de Villavicencio. Bachelor thesis, Universidad Santo Tomás. Available at http://hdl.handle.net/11634/19512 (accessed 2020 January 25)

Parrado CE. 2020. Desagregación espacial y temporal del inventario de emisiones por fuentes fijas para la ciudad de Villavicencio-META. Bachelor thesis, Universidad Santo Tomás. Available at http://hdl.handle. net/11634/21747 (accessed 2020 March 25)

Peixoto JP, and Oort A.H. 1992. Physics of Climate. American Institute of Physics, 520 pp.

Pereira SN, Wagner F, and Silva AM. 2012. Long term black carbon measurements in the southwestern Iberia Peninsula. Atmospheric Environment 57: 63-71. https://doi.org/10.1016/j.atmosenv.2012.04.050

Phuleria HC, Fine PM, Zhu Y, and Sioutas C. 2005. Air quality impacts of the October 2003 Southern California wildfires. Journal. Geophysical Research, Atmospheres 110: 1-11. https://doi.org/10.1029/ 2004JD004626

Pivello VR. 2011. The use of fire in the cerrado and Amazonian rainforests of Brazil: Past and present. Fire Ecology 7: 24-39. https://doi.org/10.4996/fireecology.0701024

Poveda G, Waylen PR, and Pulwarty RS. 2006. Annual and inter-annual variability of the present climate in northern South America and southern Mesoamerica. Palaeogeography, Palaeoclimatology, Palaeoecology 234: 3-27. https://doi.org/10.1016/j. palaeo.2005.10.031

Prospero JM, Collard FX, Molinié J, and Jeannot A. 2014. Characterizing the annual cycle of African dust transport to the Caribbean Basin and South America and its impact on the environment and air quality. Global Biogeochemical. Cycles 28: 757-773. https:// doi.org/10.1002/2013GB004802

Provençal S, Buchard V, da Silva AM, Leduc R, and Barrette N. 2017. Evaluation of PM surface concentrations simulated by Version 1 of NASA's MERRA Aerosol Reanalysis over Europe. Atmospheric Pollution Research 8: 374-382. https://doi.org/10.1016/j. apr.2016.10.009

Pulwarty RS, Barry RG, Hurst CM, Sellinger K, and Mogollon LF. 1998. Precipitation in the Venezuelan Andes in the context of regional climate. Meteorology and Atmospheric Physics 67: 217-237. https://doi. org/10.1007/BF01277512
Randles CA, Silva AM, Buchard V, Colarco PR, Darmenov A, Govindaraju R, Smirnov A, Holben B, Ferrare R, Hair J, Shinozuka Y, Flynn CJ. 2017. The MERRA-2 Aerosol Reanalysis, 1980 Onward. Part I: System Description and Data Assimilation Evaluation. Journal of Climate 30: 6823-6850. https://doi.org/10.1175/ jcli-d-16-0609.1

Reid JS, Koppmann R, Eck TF, and Eleuterio DP. 2005. A review of biomass burning emissions, part II: Intensive physical properties of biomass burning particles. Atmospheric Chemistry and Physics 5: 799-825. https:// doi.org/10.5194/acp-5-799-2005

Rienecker MM, Suarez MJ, Gelaro R, Todling R, Bacmeister J, Liu E, Bosilovich MG, Schubert SD, Takacs L, Kim G-K, Bloom S, Chen J, Collins D, Conaty A, da Silva A, Gu W, Joiner J, Koster RD, Lucchesi R, Molod A, Owens T, Pawson S, Pegion P, Redder CR, Reichle R, Robertson FR, Ruddick AG, Sienkiewicz M, and Woollen J. 2011. MERRA: NASA's Modern-Era Retrospective Analysis for Research and Applications. Journal of Climate 24: 3624-3648. https:// doi.org/10.1175/JCLI-D-11-00015.1

Rincón-Riveros JM, Rincón-Caro MA, Sullivan A, Mendez-Espinosa JF, Belalcazar LC, Quirama-Aguilar M, and Morales-Betancourt R. 2020. Long-term Brown Carbon and Smoke Tracer Observations in Bogotá, Colombia: Association to Medium-Range Transport of Biomass Burning Plumes. Atmospheric Chemistry and Physics 20: 7459-7472. https://doi.org/10.5194/ acp-20-7459-2020

Rubio M, Lissi E, Gramsch E, and Garreaud R. 2015. Effect of Nearby Forest Fires on Ground Level Ozone Concentrations in Santiago, Chile. Atmosphere 6: 1926-1938. https://doi.org/10.3390/atmos6121838

Schultz MG, Heil A, Hoelzemann JJ, Spessa A, Thonicke K, Goldammer JG, Held AC, Pereira JMC, and van het Bolscher M. 2008. Global wildland fire emissions from 1960 to 2000. Global Biogeochemical Cycles 22: GB2002, https://doi.org/10.1029/2007GB003031

Schutgens N, Miyoshi T, Takemura T, and Nakajima T. 2010. Applying an ensemble Kalman filter to the assimilation of AERONET observations in a global aerosol transport model. Atmospheric Chemistry and Physics 10: 2561-2576. https://doi.org/10.5194/acp10-2561-2010

Song Z, Fu D, Zhang X, Wu Y, Xia X, He J, Han X, Zhang R, and Che H. 2018. Diurnal and seasonal variability of PM2.5 and AOD in North China plain: Comparison 
of MERRA-2 products and ground measurements. Atmospheric Environment 191: 70-78. https://doi. org/10.1016/j.atmosenv.2018.08.012

Srimuruganandam B, and Shiva Nagendra SM. 2011. Chemical characterization of PM10 and PM2.5 mass concentrations emitted by heterogeneous traffic. Science of the Total Environment, 409(17), 3144-3157. https://doi.org/10.1016/j.scitotenv.2011.04.042

Stein AF, Draxler RR, Rolph GD, Stunder BJB, Cohen MD, and Ngan F. 2015. NOAA's HYSPLIT Atmospheric Transport and Dispersion Modeling System. Bulletin of the American Meteorological Society 96: 2059-2077. https://doi.org/10.1175/BAMS-D-14-00110.1

Subramanian R, Kok GL, Baumgardner D, Clarke A, Shinozuka Y, Campos TL, Heizer CG, Stephens BB, De Foy B, Voss PB, and Zaveri RA. 2010. Black carbon over Mexico: The effect of atmospheric transport on mixing state, mass absorption cross-section, and $\mathrm{BC} /$ $\mathrm{CO}$ ratios. Atmospheric Chemistry and Physics 10: 219-237. https://doi.org/10.5194/acp-10-219-2010

Targino AC, Gibson MD, Krecl P, Rodrigues MVC, dos Santos MM, and dePaula Corrêa M. 2016. Hotspots of black carbon and PM2.5 in an urban area and relationships to traffic characteristics. Environmental Pollution 218: 475-486. https://doi.org/10.1016/j.envpol.2016.07.027

Teichmann C. 2010. Climate and air pollution modelling in South America with focus on megacities. PhD Thesis, Hamburg University, Hamburg. https://doi. org/10.17617/2.993870

Thornhill GD, Ryder CL, Highwood EJ, Shaffrey LC, and Johnson BT. 2018. The effect of South American biomass burning aerosol emissions on the regional climate. Atmospheric Chemistry and Physics 18: 5321-5342. https://doi.org/10.5194/acp-18-5321-2018

Torrealba ER, and Amador JA. 2010. La corriente en chorro de bajo nivel sobre los Llanos Venezolanos de Sur América. Revista de Climatología 10, 1-20.

Trujano-Jiménez F, Ríos B, Jaramillo A, Ladino LA, and Raga GB. 2021. The impact of biomass burning emissions on Protected Natural Areas in central and southern Mexico. Environmental Science and Pollution Research 28: 17275-17289. https://doi.org/10.1007/ s11356-020-12095-y

Ukhov A, Mostamandi S, Silva A, Flemming J, Alshehri Y, Shevchenko I, and Stenchikov G. 2020. Assessment of natural and anthropogenic aerosol air pollution in the Middle East using MERRA-2, CAMS data assimilation products, and high-resolution WRF-Chem model simulations. Atmospheric Chemistry and Physics, 20(15), 9281-9310. https://doi.org/10.5194/acp-20-9281-2020

United States Environmental Protection Agency USEPA. 2017. Measurement Quality Objectives and Validation Templates (Vol. II, Appendix D). Available at https://www.epa.gov/sites/production/ files/2020-10/documents/app_d_validation_template_version_03_2017_for_amtic_rev_1.pdf (accessed 2020 January 20)

Urban RC, Lima-Souza M, Caetano-Silva L, Queiroz MEC, Nogueira RF, Allen AG, Cardoso AA, Held G, and Campos MLA. 2012. Use of levoglucosan, potassium, and water-soluble organic carbon to characterize the origins of biomass-burning aerosols. Atmospheric Environment 61: 562-569.https://doi.org/10.1016/j. atmosenv.2012.07.082

Van Der Werf GR, Randerson JT, Giglio L, Collatz GJ, Mu M, Kasibhatla PS, Van Leeuwen TT. 2010. Global fire emissions and the contribution of deforestation, savanna, forest, agricultural, and peat fires (1997-2009). Atmospheric Chemistry and Physics 10: 11707-11735. https://doi.org/10.5194/acp-10-11707-2010

World Health Organization WHO 2018. Health, environment and climate change. Road map for an enhanced global response to the adverse health effects of air pollution. Available at https://apps.who.int/iris/handle/10665/276321 (accessed 2020 January 25)

Xiao Q, Chang H, Geng G, and Liu Y. 2018. An Ensemble Machine-Learning Model To Predict Historical PM 2.5 Concentrations in China from Satellite Data. Environmental Science and Technology 52: 13260-13269. https://doi.org/10.1021/acs.est.8b02917

$\mathrm{Xu}$ L, Chen X, Chen J, Zhang F, He C, Zhao J, and Yin L. 2012. Seasonal variations and chemical compositions of PM 2.5 aerosol in the urban area of Fuzhou, China. Atmospheric Research 104-105: 264-272. https://doi. org/10.1016/j.atmosres.2011.10.017

Yin L, Niu Z, Chen X, Chen J, Xu L, and Zhang F. 2012. Chemical compositions of PM2.5 aerosol during haze periods in the mountainous city of Yong'an, China. Journal of Environmental Sciences 24: 1225-1233. https://doi.org/10.1016/S1001-0742(11)60940-6 


\section{Supplemental material}



Fig. S1: $\mathrm{PM}_{10}$ and $\mathrm{O}_{3}$ daily profiles from La Esmeralda and Catumate stations, respectively.



b

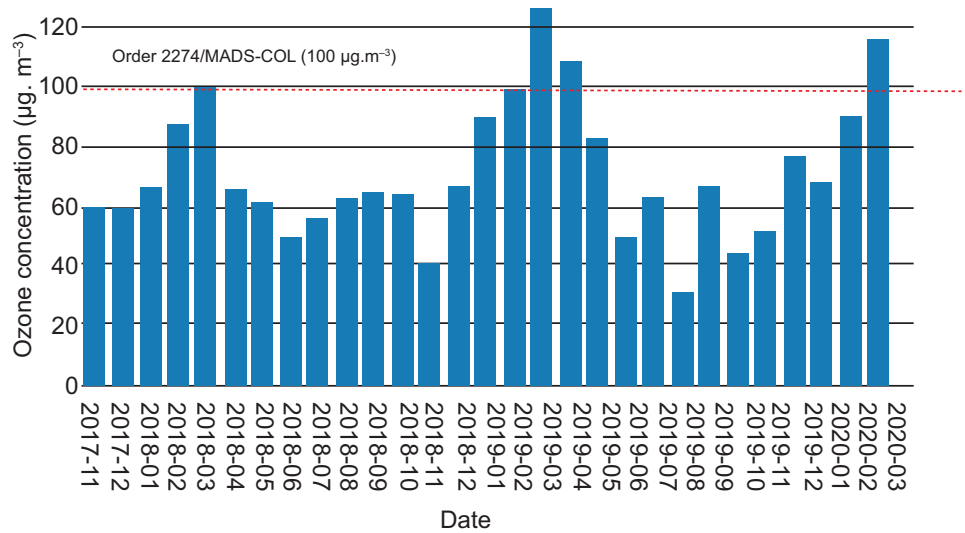

Fig. S2: a) $24 \mathrm{~h}$ moving average of $\mathrm{PM}_{10}$ from La Esmeralda station, and b) $8 \mathrm{~h}$ moving average of $\mathrm{O}_{3}$ from the Catumare station. The daily maxima of the moving averages were used in this figure. While the orange and red dotted lines in a) depict the Colombian and WHO air quality standards for $\mathrm{PM}_{10}$, the red dotted line in b) depict the Colombian and $\mathrm{WHO}$ air quality standards for $\mathrm{O}_{3}$. 


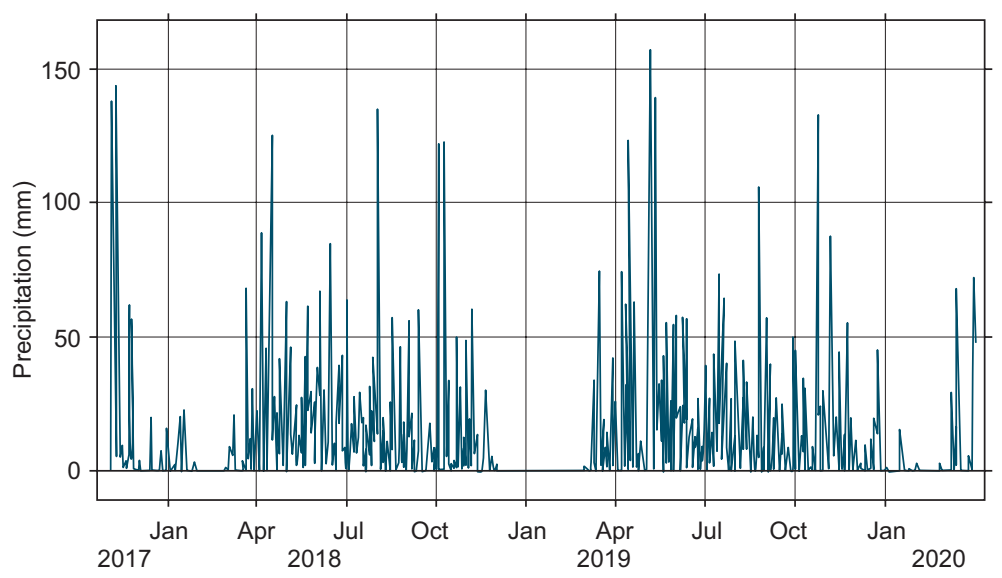

Fig, S3. Daily accumulated precipitation time series between November 2017 and March 2010.
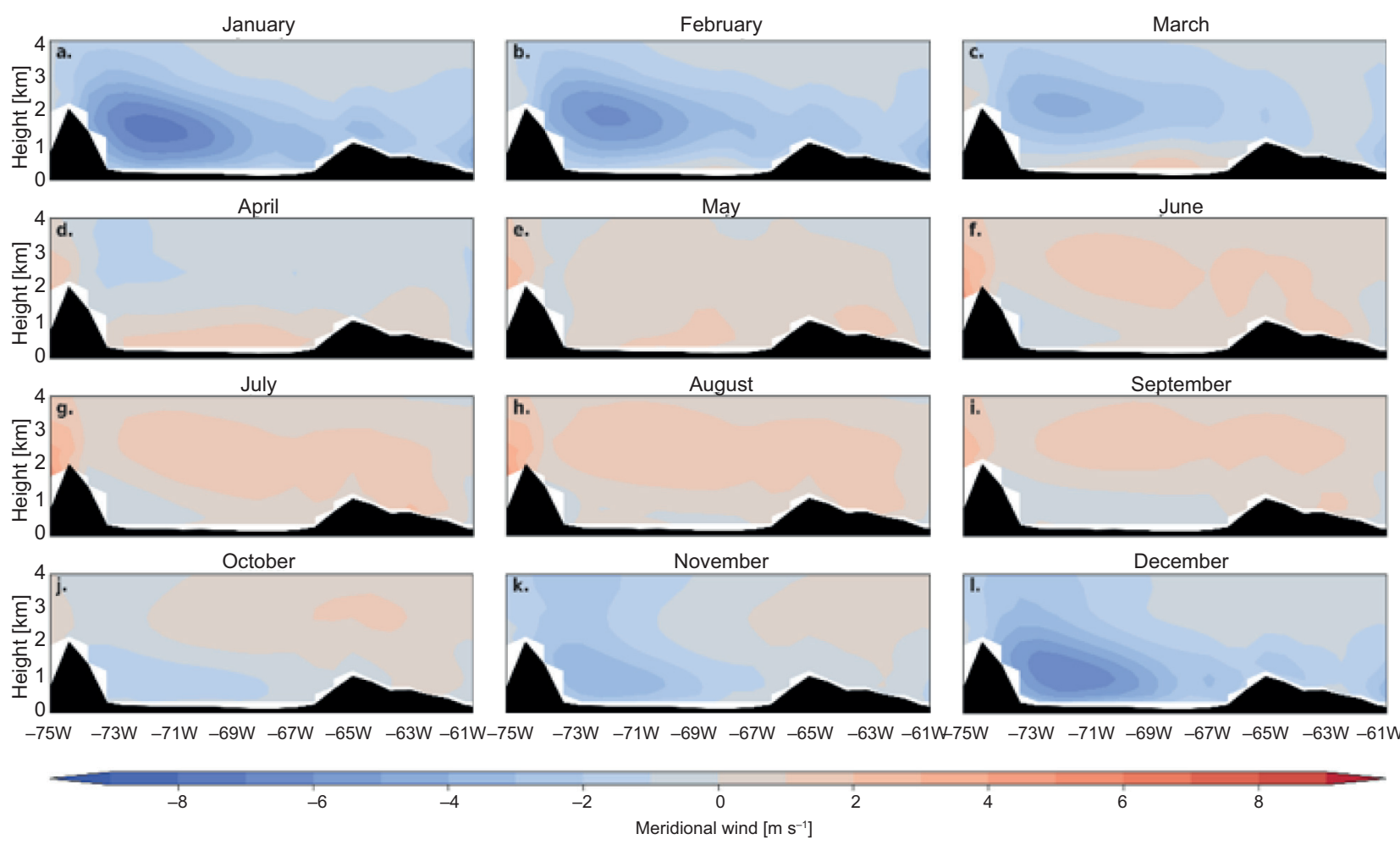

Fig. S4: Vertical Orinoco low level jet climatology. 


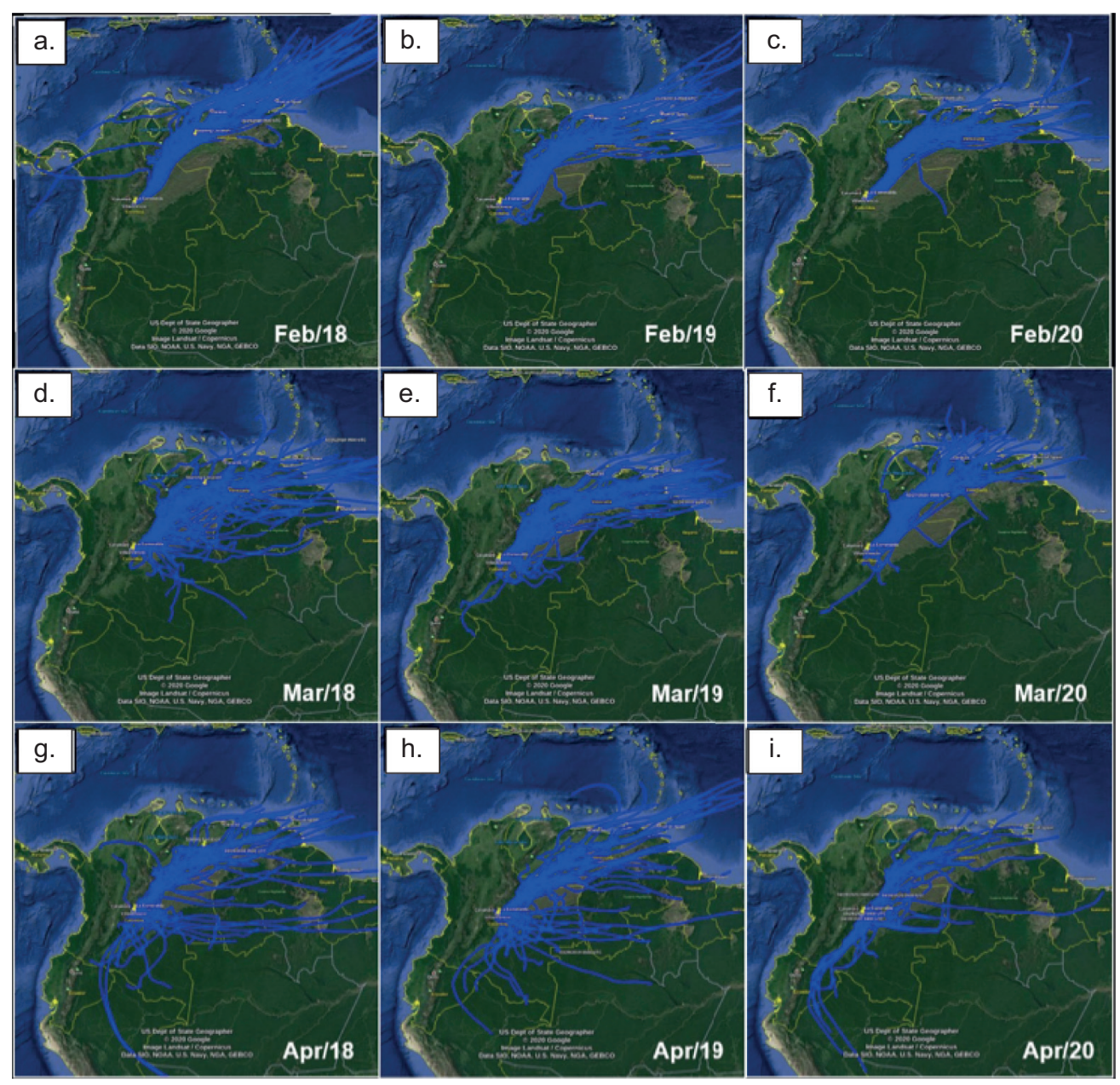

Figure S5: 72-hours back trajectories during the BB season in the ORIB region represented by blue lines. a) February 2018, b) February 2019, c) February 2020, d) March 2018, e) March 2019, f) March 2020, g) April 2018, h) April 2019, and i) April 2020. 


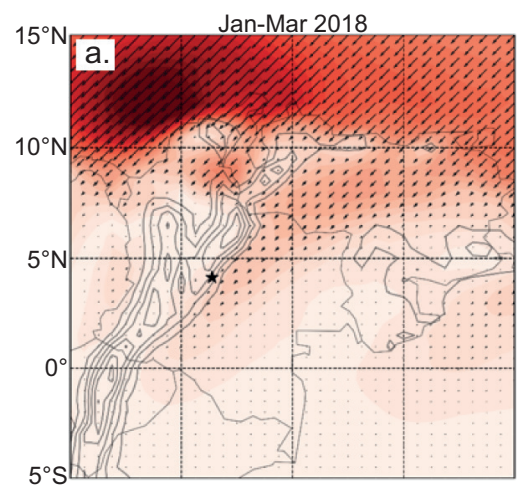

Apr-Jun 2018


Vertically integrated sea salt transport $\left[\mathrm{g} \mathrm{m}^{-1} \mathrm{~s}^{-1}\right]$

Fig. S6: Mean SS low-level flux for the period a) January-March 2018, b) January-March 2019, c) April-June 2018, and d) April-June 2019.

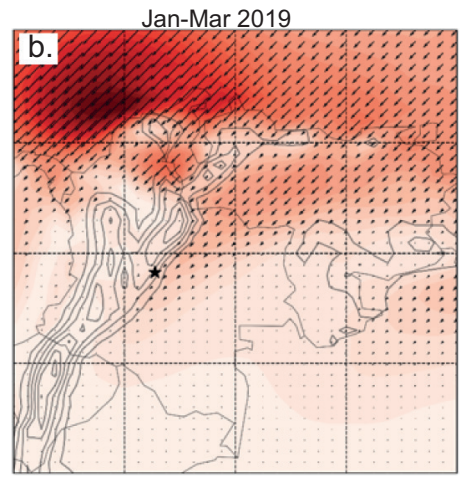

Apr-Jun 2019

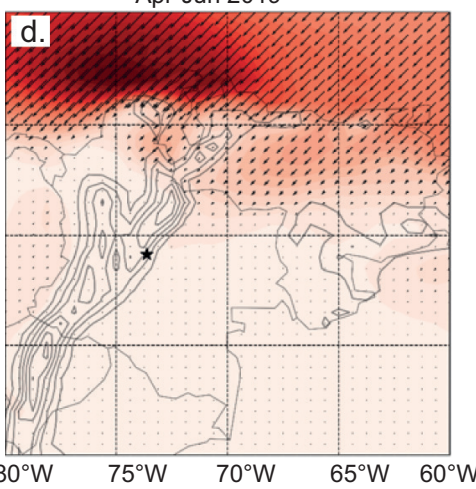

1.05 

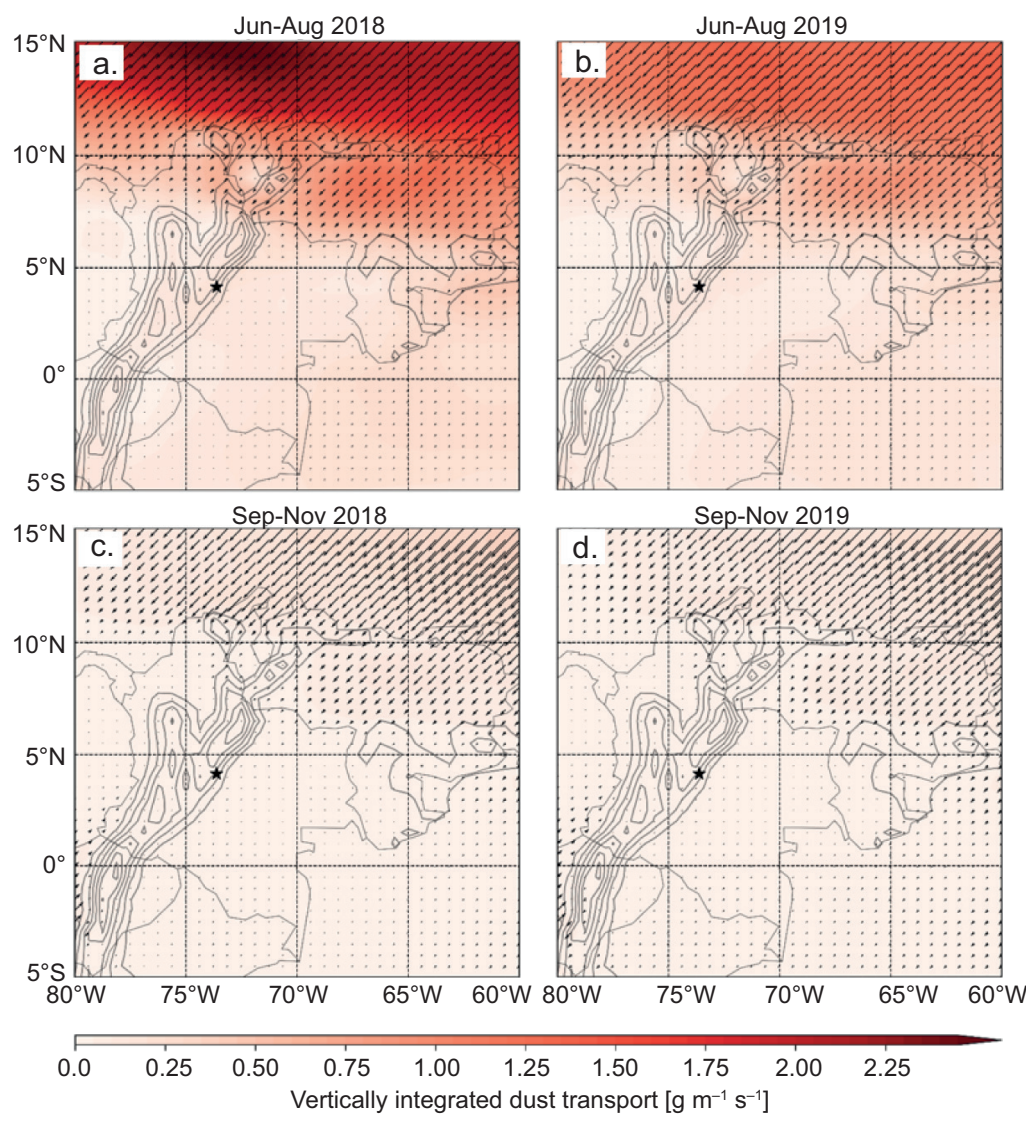

Fig. S7: Mean DS low-level flux for the period a) June-August 2018, b) June-August 2019, c) September-November 2018, and d) September-November 2019. 